\title{
Synthesis and Biological Action of Novel 4-Position-Modified Derivatives of D-myo-Inositol 1,4,5-Trisphosphate
}

\author{
Davide Bello, ${ }^{\dagger}$ Tashfeen Aslam, ${ }^{\dagger}$ Geert Bultynck, ${ }^{\dagger}$ Alexandra M. Z. Slawin, ${ }^{\dagger}$ \\ H. Llewelyn Roderick, ${ }^{\S}$ Martin D. Bootman, ${ }^{\S}$ and Stuart J. Conway*, ${ }^{\dagger}$ \\ EaStCHEM and School of Chemistry, Centre for Biomolecular Sciences, University of St Andrews, \\ North Haugh, St Andrews, Fife KY16 9ST, United Kingdom, Laboratory of Molecular Signalling, \\ Campus Gasthuisberg O/N1, Katholieke Universiteit Leuven, Herestraat 49, Bus 802, B-3000 Leuven, \\ Belgium, and Laboratory of Molecular Signalling, The Babraham Institute, Babraham, \\ Cambridge CB22 3AT, United Kingdom \\ sjc16@st-andrews.ac.uk
}

Received March 29, 2007

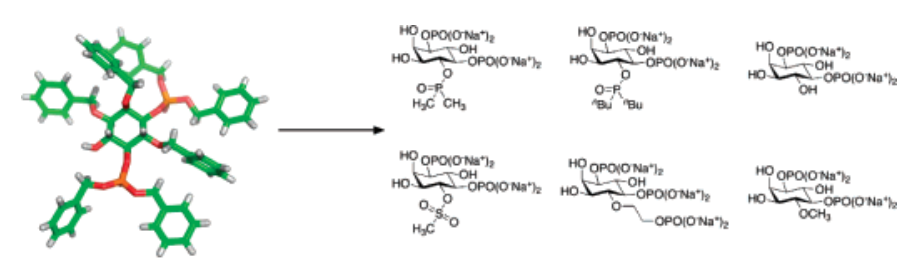

The design of a range of 4-position-modified D-myo-inositol 1,4,5-trisphosphate derivatives is described. The enantioselective synthesis of these compounds is reported, along with initial biological analysis, which indicates that these compounds do not act as D-myo-inositol 1,4,5-trisphosphate receptor agonists or antagonists.

\section{Introduction}

It is well-established that D-myo-inositol 1,4,5-trisphosphate (Ins $P_{3}, 1$; Figure 1) is a ubiquitous intracellular $\mathrm{Ca}^{2+}$-releasing second messenger that mediates a wide range of cellular functions. ${ }^{1}$ Ins $P_{3}$ is generated following G-protein activation, as a result of extracellular receptor stimulation, which initiates the intracellular PLC-mediated hydrolysis of phosphatidylinositol 4,5-bisphosphate [2, PtdIns(4,5) $P_{2}$ ] to afford $\operatorname{Ins} P_{3}$ and diacylglycerol (DAG). Both of these compounds perform important signaling roles within cells; DAG mediates its cellular function through the activation of some isoforms of PKC. Ins $P_{3}$ is hydrophilic and diffuses through the cytosol to activate its specific receptors (Ins $P_{3} \mathrm{Rs}$ ), which are located predominantly on the endoplasmic or sarcoplasmic reticulum membrane. Activation of these Ins $P_{3}$-gated ion channels leads to the release of intracellular $\mathrm{Ca}^{2+}$ into the cytosol and a plethora of subsequent signaling events, including cell proliferation, muscle contraction, apoptosis, and gene transcription. $\mathrm{Ca}^{2+}$ signaling is also involved in fundamental processes such as fertilization,

* To whom correspondence should be addressed. Phone: +44 (0) 1334 463478. Fax: +44 (0) 1334463808 .

$\dagger$ University of St Andrews.

* Katholieke Universiteit Leuven.

$\S$ The Babraham Institute.

(1) Berridge, M. J.; Bootman, M. D.; Roderick, H. L. Nat. Rev. Mol. Cell Biol. 2003, 4, 517. behavior, memory, and learning. ${ }^{1}$ It is now clear that the $\operatorname{Ins} P_{3}$ signaling cascade resides downstream of the receptors for most important endogenous chemical transmitters, including acetylcholine, adrenaline, dopamine, glutamate, and serotonin, in addition to some tyrosine kinase receptors. ${ }^{1}$ The biochemical importance of $\operatorname{Ins} P_{3}$ has prompted many syntheses of $\operatorname{Ins} P_{3}$ and numerous unnatural derivatives. ${ }^{2,3}$ These compounds have proved vital in establishing the structural characteristics required for agonist activity at Ins $P_{3}$ Rs. Especially useful compounds include the metabolically stable phosphorothioates ${ }^{2,3}$ the adenophostins, ${ }^{4-11}$ photoactivated Ins $P_{3}$ derivatives, ${ }^{12,13}$ and membrane-permeant Ins $P_{3}$ derivatives. ${ }^{12,14,15}$

(2) Conway, S. J.; Miller, G. J. Nat. Prod. Rep., in press.

(3) Potter, B. V. L.; Lampe, D. Angew. Chem., Int. Ed. Engl. 1995, 34, 1933

(4) Morris, S. A.; Nerou, E. P.; Riley, A. M.; Potter, B. V. L.; Taylor, C. W. Biochem. J. 2002, 367, 113.

(5) Correa, V.; Riley, A. M.; Shuto, S.; Horne, G.; Nerou, E. P.; Marwood, R. D.; Potter, B. V. L.; Taylor, C. W. Mol. Pharmacol. 2001, 59, 1206.

(6) Marwood, R. D.; Correa, V.; Taylor, C. W.; Potter, B. V. L., Tetrahedron: Asymmetry 2000, 11, 397.

(7) Marwood, R. D.; Shuto, S.; Jenkins, D. J.; Potter, B. V. L. Chem. Commun. 2000, 219.

(8) vanStraten, N. C. R.; vanderMarel, G. A.; vanBoom, J. H. Tetrahedron 1997, 53, 6509.

(9) vanStraten, N. C. R.; vanderMarel, G. A.; vanBoom, J. H. Tetrahedron Lett. 1996, 37, 3599. 


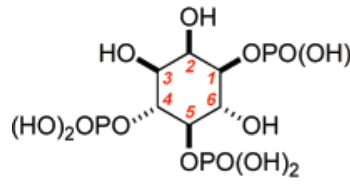

1

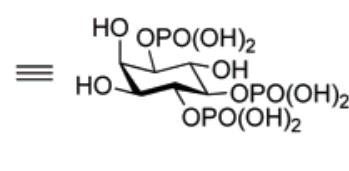

1

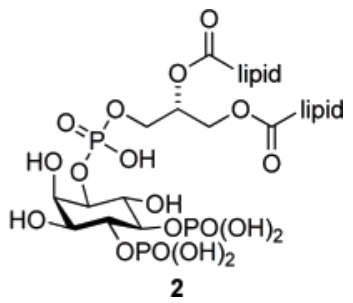

2
FIGURE 1. Structures of $\operatorname{Ins} P_{3}(\mathbf{1})$ and $\operatorname{Ptd} \operatorname{Ins}(4,5) P_{2}(\mathbf{2})$.

In contrast, there are very few compounds that act as selective antagonists of the Ins $P_{3}$ Rs. ${ }^{3,16}$ 2-Aminoethoxy diphenyl borate (2-APB) is the most commonly used Ins $P_{3} \mathrm{R}$ antagonist, as it is readily available and also membrane permeant. ${ }^{17}$ However, 2-APB is not selective for Ins $P_{3}$ Rs and displays a number of other actions including inhibition of SERCA pumps, ${ }^{18}$ inhibition of store-operated $\mathrm{Ca}^{2+}$ entry, ${ }^{19,20}$ activation of TRPV1-3, ${ }^{21,22}$ inhibition of TRPC $5,{ }^{23}$ interactions with TRPM6 and TRPM7, and possibly inhibition of $\mathrm{Ca}^{2+}$ ATPases. ${ }^{20}$ Xestospongin $\mathrm{C}$, a marine natural product that was isolated in $1984,{ }^{24}$ has also been reported to inhibit $\mathrm{Ca}^{2+}$ release from Ins $P_{3} \mathrm{Rs}^{25,26}$ This compound is potentially useful as, like $2-\mathrm{APB}$, it is membrane permeant; however, xestospongin $\mathrm{C}$ does not selectively interact with Ins $P_{3}$ Rs and is known to inhibit SERCA pumps. ${ }^{25,27}$ More recently, the structurally related xestospongin $\mathrm{B}$ has been reported as a competitive inhibitor of $\operatorname{Ins} P_{3}$-mediated $\mathrm{Ca}^{2+}$ signaling. ${ }^{28}$ Heparin and decavanadate also act as $\operatorname{Ins} P_{3} \mathrm{R}$ antagonists, but are not membrane permeant and thus not suitable for use in many situations. ${ }^{3,29}$ Benzene-1,2,4-triol has been reported to competitively block Ins $P_{3}$ binding to adrenal

(10) Takahashi, M.; Tanzawa, K.; Takahashi, S. J. Biol. Chem. 1994, $269,369$.

(11) Takahashi, M.; Kagasaki, T.; Hosoya, T.; Takahashi, S. J. Antibiot. 1993, 46, 1643

(12) Li, W. H.; Llopis, J.; Whitney, M.; Zlokarnik, G.; Tsien, R. Y. Nature 1998, 392, 936.

(13) Walker, J. W.; Feeney, J.; Trentham, D. R. Biochemistry 1989, 28 , 3272 .

(14) Conway, S. J.; Thuring, J. W.; Andreu, S.; Kvinlaug, B. T.; Roderick, H. L.; Bootman, M. D.; Holmes, A. B. Aust. J. Chem. 2006, 59, 887.

(15) Li, W. H.; Schultz, C.; Llopis, J.; Tsien, R. Y. Tetrahedron 1997, $53,12017$.

(16) Bultynck, G.; Sienaert, I.; Parys, J. B.; Callewaert, G.; De Smedt, H.; Boens, N.; Dehaen, W.; Missiaen, L. Pfluegers Arch. 2003, 445, 629

(17) Maruyama, T.; Kanaji, T.; Nakade, S.; Kanno, T.; Mikoshiba, K. Jpn. J. Biochem. 1997, 122, 498.

(18) Bilmen, J. G.; Wootton, L. L.; Godfrey, R. E.; Smart, O. S.; Michelangeli, F. Eur. J. Biochem. 2002, 269, 3678.

(19) Bootman, M. D.; Collins, T. J.; Mackenzie, L.; Roderick, H. L.; Berridge, M. J.; Peppiatt, C. M. FASEB J. 2002, 16.

(20) Peppiatt, C. M.; Collins, T. J.; Mackenzie, L.; Conway, S. J.; Holmes, A. B.; Bootman, M. D.; Berridge, M. J.; Seo, J. T.; Roderick, H. L. Cell Calcium 2003, 34, 97.

(21) Hu, H. Z.; Gu, Q. H.; Wang, C. B.; Colton, C. K.; Tang, J. S.; Kinoshita-Kawada, M.; Lee, L. Y.; Wood, J. D.; Zhu, M. X. J. Biol. Chem. 2004, 279, 35741.

(22) Chung, M. K.; Lee, H.; Mizuno, A.; Suzuki, M.; Caterina, M. J. J. Neurosci. 2004, 24, 5177.

(23) Xu, S. Z.; Zeng, F. N.; Boulay, G.; Grimm, C.; Harteneck, C.; Beech, D. J. Br. J. Pharmacol. 2005, 145, 405.

(24) Nakagawa, M.; Endo, M.; Tanaka, N.; Lee, G. P. Tetrahedron Lett. 1984, 25, 3227

(25) De Smet, P.; Parys, J. B.; Callewaert, G.; Weidema, A. F.; Hill, E.; De Smedt, H.; Erneux, C.; Sorrentino, V.; Missiaen, L. Cell Calcium 1999, $26,9$.

(26) Gafni, J.; Munsch, J. A.; Lam, T. H.; Catlin, M. C.; Costa, L. G.; Molinski, T. F.; Pessah, I. N. Neuron 1997, 19, 723.

(27) Castonguay, A.; Robitaille, R. Cell Calcium 2002, 32, 39.

(28) Jaimovich, E.; Mattei, C.; Liberona, J. L.; Cardenas, C.; Estrada, M.; Barbier, J.; Debitus, C.; Laurent, D.; Molgo, J. FEBS Lett. 2005, 579, 2051. cortex microsomes $\left(\mathrm{IC}_{50}=34 \mathrm{mM}\right)$. The affinity of this compound for the Ins $P_{3}$ Rs is about 10000 -fold less than that of Ins $P_{3}$ and did not evoke $\mathrm{Ca}^{2+}$ release itself. ${ }^{3}$ Erneux and coworkers have recently reported that another aromatic compound, biphenyl 2,3',4,5',6-pentakisphosphate, inhibits $\operatorname{Ins} P_{3}$-induced $\mathrm{Ca}^{2+}$ release by blocking Ins $P_{3}$ binding to the Ins $P_{3}$ Rs. However, this compound is also known to act as an $\operatorname{Ins} P_{3} 5$-phosphatase inhibitor. ${ }^{30}$ The only Ins $P_{3} \mathrm{R}$ antagonist based on the inositol architecture, to date, is the methylphosphonate reported by Dreef and co-workers. ${ }^{31}$ Extensive pharmacological studies of this molecule have not been published, as the production of the required quantity of material presents a significant synthetic challenge. In addition, the phosphate groups of this compound would have to be modified for it to cross the cell membrane. It is therefore clear that the development of selective, membranepermeant $\operatorname{Ins} P_{3} \mathrm{R}$ antagonists is vital to enable further studies of $\mathrm{Ca}^{2+}$ and $\mathrm{Ins} P_{3}$ signaling.

The publication of the X-ray crystal structure of the Ins $P_{3^{-}}$ binding domain of the mouse type $1 \operatorname{Ins} P_{3} \mathrm{R}$ provides a wealth of information on the binding interaction of $\operatorname{Ins} P_{3}$ with its receptor. ${ }^{32}$ Only the ligand-bound structure was reported, which is assumed to be in the "active" conformation. The apo form of the binding domain would have provided further information about the structure requirements for antagonist activity at $\operatorname{Ins} P_{3}$ Rs, as it can simplistically be assumed that an antagonist will bind to the "inactive" form of the receptor. Nonetheless, we have used this information to assist in the design of a range of potential Ins $P_{3} \mathrm{R}$ antagonists.

From the X-ray crystal structure it can be seen that $\operatorname{Ins} P_{3}$ binds in a cleft between the $\alpha$-domain and the $\beta$-domain of the Ins $P_{3}$-binding domain (Figure 2). Closer inspection reveals that the 1-position phosphate group (P1) of $\operatorname{Ins} P_{3}$ binds to residues R568 and K569 and the 5-position phosphate (P5) binds to residues R504, K508, R511, and Y567 on the $\alpha$-domain. Conversely, the 4-position phosphate ( $\mathrm{P} 4)$ binds predominantly to residues on the $\beta$-domain, T266, T267, G268, and K569. In addition, both P4 and P5 bind to R265 and R269 on the $\beta$-domain (Figure 3).

Studies conducted by Mignery and Sudhof demonstrated that Ins $P_{3}$ binding to the Ins $P_{3}$ Rs causes a large conformation change of the protein. ${ }^{33}$ Since the publication of the X-ray crystal structure of the mouse type $1 \operatorname{Ins} P_{3} R$, it has been widely postulated that this conformational change occurs as a result of

(29) Tones, M. A.; Bootman, M. D.; Higgins, B. F.; Lane, D. A.; Pay, G. F.; Lindahl, U. FEBS Lett. 1989, 252, 105.

(30) Vandeput, F.; Combettes, L.; Mills, S. J.; Backers, K.; Wohlkonig, A.; Parys, J. B.; De Smedt, H.; Missiaen, L.; Dupont, D.; Potter, B. V. L.; Erneux, C. FASEB J. 2007, 21, 1481.

(31) Dreef, C. E.; Schiebler, W.; Vandermarel, G. A.; Vanboom, J. H. Tetrahedron Lett. 1991, 32, 6021.

(32) Bosanac, I.; Alattia, J. R.; Mal, T. K.; Chan, J.; Talarico, S.; Tong, F. K.; Tong, K. I.; Yoshikawa, F.; Furuichi, T.; Iwai, M.; Michikawa, T.; Mikoshiba, K.; Ikura, M. Nature 2002, 420, 696.

(33) Mignery, G. A.; Sudhof, T. C. EMBO J. 1990, 9, 3893. 


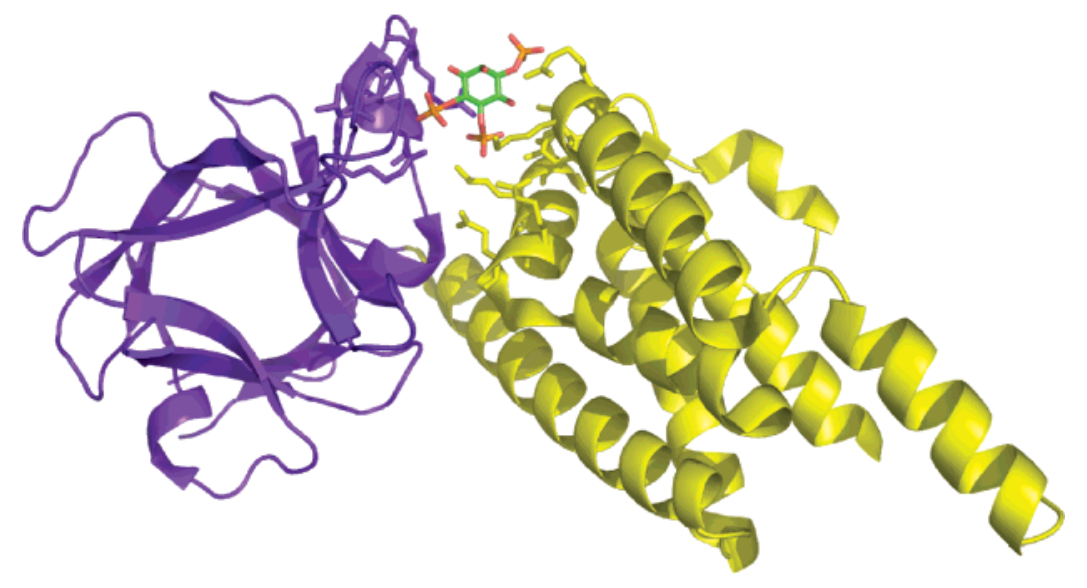

FIGURE 2. A cartoon representation of the X-ray crystal structure of the mouse type 1 Ins $P_{3} \mathrm{R}$ reported by Bosanac and co-workers. ${ }^{32}$ It can be seen that Ins $P_{3}$ binds between the $\alpha$-domain (yellow) and $\beta$-domain (purple).

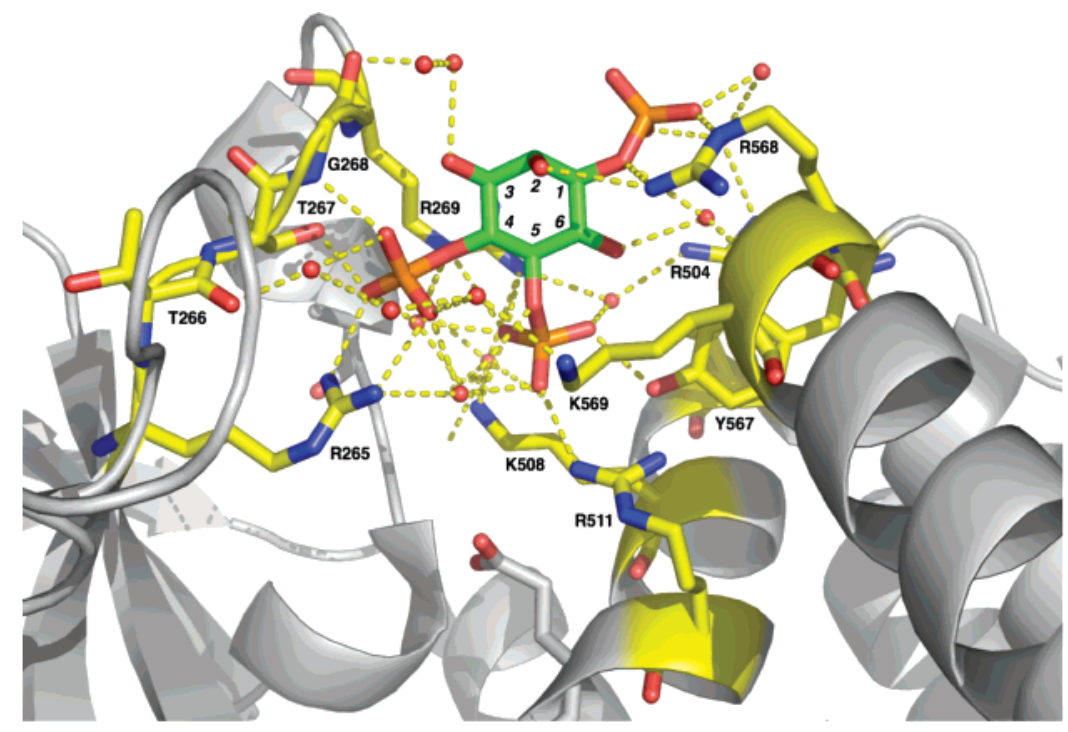

FIGURE 3. A cartoon representation of the X-ray crystal structure of the mouse type 1 Ins $P_{3} \mathrm{R}$ showing that $\mathrm{P} 1$ of Ins $P_{3}$ binds to residues R568 and K569 and P5 binds to residues R504, K508, R511, and Y567, which are all on the $\alpha$-domain. Conversely, P4 binds predominantly to residues on the $\beta$-domain, T266, T267, G268, and K569. In addition, both P4 and P5 bind to R265 and R269.

Ins $P_{3}$ binding between the $\alpha$-domain and the $\beta$-domain, causing the two domains to close together in a clam-shell-like manner. ${ }^{34}$ It is thought that this movement allows binding of $\mathrm{Ca}^{2+}$ to the Ins $P_{3}$ Rs and ultimately receptor activation. This method of receptor activation is not uncommon and is present in the subtype 1 metabotropic glutamate receptors, for example. ${ }^{35}$

If the mechanism of receptor activation is dependent on closing of the clam shell, it can be suggested that compounds that are able to bind to one domain but not the other will be able to bind to the Ins $P_{3}$ Rs but not activate them and hence would act as competitive antagonists. As P1 and P5 bind predominantly to the $\alpha$-domain and P4 binds predominantly to the $\beta$-domain, we decided to investigate the effect of altering the P4 substituent to develop compounds that would still be able to bind to the Ins $P_{3}$ Rs through P1 and P5. However, the

(34) Taylor, C. W.; da Fonseca, P. C. A.; Morris, E. P. Trends Biochem. Sci. 2004, 29, 210.

(35) Kunishima, N.; Shimada, Y.; Tsuji, Y.; Sato, T.; Yamamoto, M.; Kumasaka, T.; Nakanishi, S.; Jingami, H.; Morikawa, K. Nature 2000, 407, 971. lack of a polar 4-position substituent would prevent the compounds from interacting with the $\beta$-domain, rendering them unable to close the clam shell and hence not activate the receptor. It was hypothesised that such compounds would act as competitive antagonists of the Ins $P_{3}$ Rs.

Using the above supposition, a range of 4-position-substituted Ins $P_{3}$ derivatives was designed (3-6, Figure 4$)$. We picked uncharged substituents with approximately the same spatial geometry as a phosphate group to eliminate the formation of any salt bridges with the $\beta$-domain of the $\operatorname{Ins} P_{3}$ Rs. The dimethylphosphinate $\mathbf{3}$ and the dibutylphosphinate $\mathbf{4}$ possess the same geometry as a phosphate group and would allow us to probe the steric bulk tolerated by the receptor. Furthermore, the methanesulfonate $\mathbf{5}$ derivative would allow us to investigate the effect of replacing the phosphorus atom with an approximately tetrahedral sulfur atom. In addition, a derivative with an ethyl chain separating the 4-position phosphate group from the inositol ring (6) was also designed. The synthesis and biological evaluation of this range of compounds are described below. 


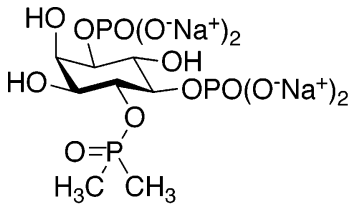

3

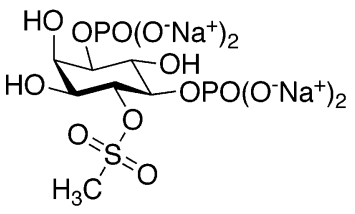

5
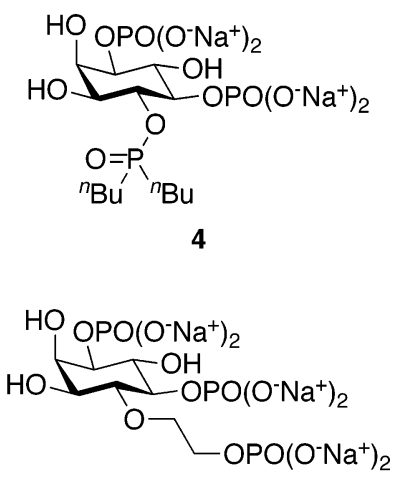

6
FIGURE 4. Structures of the 4-position-modified $\operatorname{Ins} P_{3}$ derivatives 3-6.

\section{Results and Discussion: Synthesis}

The synthetic route was designed to afford a key inositol intermediate (7) that possesses orthogonal protection between the 1- and 5-positions and the 4-position (Figure 5). It was envisaged that elaboration of the key intermediate would enable the introduction of several 4-position substituents at a late stage of the synthesis. Following the route developed by Holmes, the optically pure camphor acetal $\mathbf{8}$ (Scheme 1$)\left[[\alpha]_{\mathrm{D}}^{20}=-11.9(c\right.$ 0.2 in $\left.\mathrm{CHCl}_{3}\right)$ [lit. ${ }^{36}[\alpha]_{\mathrm{D}}^{22}=-11.7$ (c 1.3 in $\left.\left.\mathrm{CHCl}_{3}\right)\right]$ ] was obtained in seven steps from myo-inositol. ${ }^{36-39}$ Treatment of $\mathbf{8}$ with sodium hydride followed by allyl bromide yielded the fully protected inositol 9. Mild acid-catalyzed methanolysis of the camphor acetal revealed the vicinal diol 10, which was selectively benzylated at the 3-position by treatment with dibutyltin oxide and benzyl bromide. The alcohol 11 displays orthogonality between the 1- and 5-positions and the 4-position and serves as a key intermediate in the synthesis of 4-positionmodified $\operatorname{Ins} P_{3}$ derivatives.

To minimize the use of protecting groups, the installation of the dimethylphosphinate prior to the phosphate groups was attempted (Scheme 1). Treatment of the alcohol 11 with (diisopropylamino)dimethylphosphine, followed by $m \mathrm{CPBA}$ oxidation, resulted in the formation of the desired dimethylphosphinate 12. Subsequent attempts to remove the $O$-allyl protecting groups were not successful despite numerous conditions being investigated. Treatment with palladium on carbon (10\%) and toluenesulfonic acid monohydrate in methanol and water under reflux conditions afforded a $21 \%$ yield of a product that appeared to be a mixture of the desired compound and its regioisomer, in which the phosphinate had migrated to the 5-position. An alternative strategy, utilizing protection of the 4-position, deprotection of the $O$-allyl groups, and subsequent phosphorylation, followed by unmasking of the 4-position, was therefore investigated.

To develop suitable conditions for this approach, methylation of $\mathbf{1 1}$ was attempted as a model system. The alcohol $\mathbf{1 1}$ was

(36) Painter, G. F.; Grove, S. J. A.; Gilbert, I. H.; Holmes, A. B.; Raithby, P. R.; Hill, M. L.; Hawkins, P. T.; Stephens, L. R. J. Chem. Soc., Perkin Trans. 1 1999, 923.

(37) Lim, Z. Y.; Thuring, J. W.; Holmes, A. B.; Manifava, M.; Ktistakis, N. T. J. Chem. Soc., Perkin Trans. 1 2002, 1067.

(38) Painter, G. F.; Thuring, J. W.; Lim, Z. Y.; Holmes, A. B.; Hawkins, P. T.; Stephens, L. R. Chem. Commun. 2001, 645.

(39) Grove, S. J. A.; Gilbert, I. H.; Holmes, A. B.; Painter, G. F.; Hill, M. L. Chem. Commun. 1997, 1633. readily methylated to afford the methyl ether $\mathbf{1 3}$ (Scheme 2) before the $O$-allyl deprotection by Wilkinson's catalyst-mediated isomerization, followed by acid-catalyzed methanolysis of the resultant enol ether. ${ }^{37}$ Treatment of the diol 14 with bis(benzyloxy)( $N, N$-diisopropylamino)phosphine and $1 \mathrm{H}$-tetrazole, followed by oxidation, afforded the protected phosphate 15 . Hydrogenolysis of the benzyl ethers was initially attempted using palladium on carbon $(10 \%)$ in ethanol. This afforded a compound that displayed the expected mass ion upon mass spectrometric analysis. However, the ${ }^{1} \mathrm{H}$ and ${ }^{31} \mathrm{P}$ NMR spectra showed broad, unresolved peaks, and thus, the migration of the phosphate groups could not be ruled out. Therefore, the hydrogenolysis was repeated using palladium black as the catalyst in the presence of sodium bicarbonate to facilitate the formation of the sodium salt of the desired compound 16. It has previously been demonstrated that the sodium salts of phosphate groups are less susceptible to migration. ${ }^{36}$ Compound 16 exhibited well-defined peaks in both its ${ }^{1} \mathrm{H}$ and ${ }^{31} \mathrm{P}$ NMR spectra, indicating the presence of one compound. Other analytical data were consistent with the assigned structure.

Having demonstrated the feasibility of the above approach, it was necessary to introduce a protecting group that could be cleaved once the dibenzyl phosphate groups had been installed. There is precedent for a 4-methoxybenzyl (PMB) group being removed in the presence of dibenzyl phosphate esters; hence, this group was selected. ${ }^{37} \mathrm{PMB}$ protection of the 4-position hydroxyl group of alcohol $\mathbf{1 1}$ was achieved by reaction with sodium hydride and 4-methoxybenzyl chloride to afford the PMB ether 17 (Scheme 3). The conditions reported by Boons and co-workers effected efficient deprotection of the allyl groups of $\mathbf{1 7}$ to furnish the diol $\mathbf{1 8} .{ }^{40}$ The dibenzyl phosphate esters were installed under standard conditions to yield 19 before the PMB group was removed by oxidative cleavage, affording the alcohol 20.

Compound 20 was a crystalline solid, and hence, a singlecrystal X-ray structure was obtained (Figure 6). The absolute stereochemistry of compound $\mathbf{2 0}$ was confirmed unambiguously using the anomalous dispersion effect [Flack parameter 0.03(4)]. With compound 20 in hand, a range of 4-position-substituted Ins $P_{3}$ derivatives was synthesized (Scheme 4). The 4-position substituents were chosen on the basis of their ability to mimic the approximate shape and geometry of a phosphate group, but with uncharged moieties. The first group installed was the dimethylphosphinate. Initial attempts to install the dimethylphosphinate using phosphorus(III)-based reagents were unsuccessful and seemed to promote migration of the existing phosphate groups (not shown). Gratifyingly, dimethylphosphinic chloride could be successfully employed to furnish the desired compound 21 in good yield. Hydrogenolysis in the presence of sodium bicarbonate afforded the sodium salt of the desired compound 3. The dibutyl derivative $\mathbf{4}$ was synthesized in a similar manner using dibutylphosphinic chloride to afford the dibutylphosphinate 22. Hydrogenolysis in the presence of sodium bicarbonate furnished the sodium salt of the dibutylphosphinate 4. To investigate the effect of replacing phosphorus with sulfur, the methanesulfonate 23 was synthesized by reaction of the alcohol $\mathbf{2 0}$ with methanesulfonyl chloride. Hydrogenolysis under the conditions described above afforded the sodium salt of $\mathbf{5}$. For completeness, the sodium salt of D-myo-inositol 1,5-bisphosphate (24) was synthesized by hy-

(40) Boons, G. J.; Burton, A.; Isles, S. Chem. Commun. 1996, 141. 


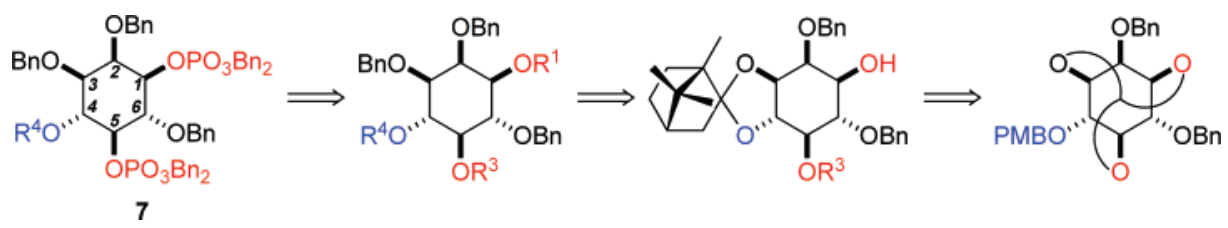

FIGURE 5. Synthetic plan for the 4-position-modified Ins $P_{3}$ derivatives.

SCHEME 1. Synthesis of the Key Intermediate $11^{a}$

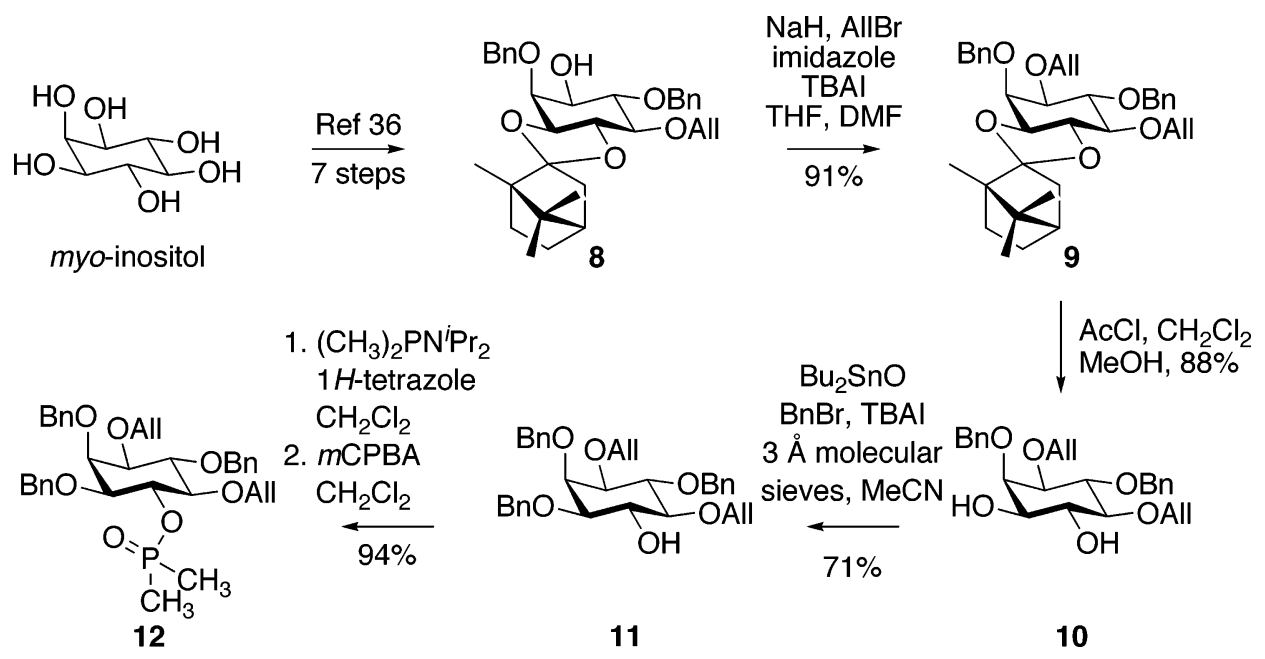

${ }^{a} \mathrm{TBAI}=$ tetrabutylammonium iodide.

SCHEME 2. Synthesis of the 4-Methyl-Ins $P_{3}$ Derivative 16
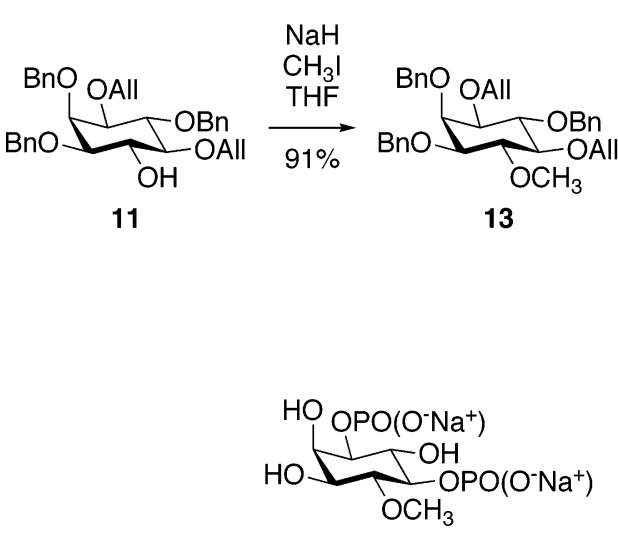

16
1. $\mathrm{Rh}\left(\mathrm{PPh}_{3}\right) \mathrm{Cl}$ DIPEA, EtOH

2. $\mathrm{AcCl}, \mathrm{CH}_{2} \mathrm{Cl}_{2}$ $\stackrel{\mathrm{MeOH}}{\longrightarrow}$ $79 \%$

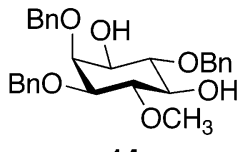

14

1. $(\mathrm{OBn})_{2} \mathrm{PN}^{i} \mathrm{Pr}_{2}$ $1 \mathrm{H}$-tetrazole, $\mathrm{CH}_{2} \mathrm{Cl}_{2}$ 2. $\mathrm{mCPBA}, \mathrm{CH}_{2} \mathrm{Cl}_{2}$ $66 \%$
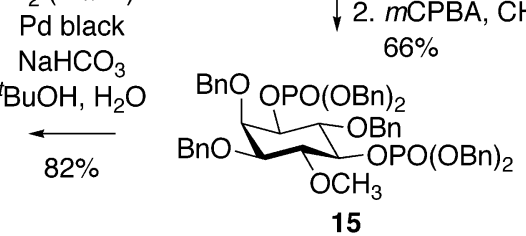

drogenolysis of $\mathbf{2 0}$ under standard conditions. All compounds were obtained as colorless lypholized powders.

The synthesis of a compound that was structurally distinct from the above series was also undertaken (Scheme 5). The concept of inserting a linker between the inositol ring and the phosphate group at the 4-position led to the design of compound 6. The synthesis of this compound commenced from the bisallyl ether 11. Reaction of the 4-position hydroxyl group with 2-(allyloxy)ethyl bromide afforded the fully protected compound 25. Removal of the allyl ethers afforded the triol 26, with phosphitylation and $m$ CPBA oxidation affording the fully perbenzylated phosphate ester 27. Hydrogenolysis of 27, using the conditions described above, furnished the desired compound 6 as its sodium salt.

\section{Results and Discussion: Biological Evaluation}

Having established a robust synthetic route to the $\operatorname{Ins} P_{3}$ derivatives 3-6, 16, and 24, we assessed the ability of these compounds to act as competitive antagonists of Ins $P_{3} \mathrm{R} 1$. The effect of the $\operatorname{Ins} P_{3}$ derivatives on the $\operatorname{Ins} P_{3}$-induced $\mathrm{Ca}^{2+}$ release was investigated in permeabilized L15 by using a unidirectional ${ }^{45} \mathrm{Ca}^{2+}$ flux assay. In this experiment, the nonmitochondrial stores of permeabilized L15 cells are loaded to steady state with ${ }^{45} \mathrm{Ca}^{2+}$, washed twice with nonlabeled efflux medium containing thapsigargin $(4 \mu \mathrm{M})$, and further incubated in a nonlabeled efflux medium. Samples were collected every $2 \mathrm{~min}$, and the loss of $\mathrm{Ca}^{2+}$ from the internal stores under these conditions was plotted as fractional $\mathrm{Ca}^{2+}$ loss $(\% / 2 \mathrm{~min})$ as a function of time. Challenging the cells with $\operatorname{Ins} P_{3} \mathrm{R}$ agonists leads to an increase 
SCHEME 3. Synthesis of the Key Intermediate $20^{a}$
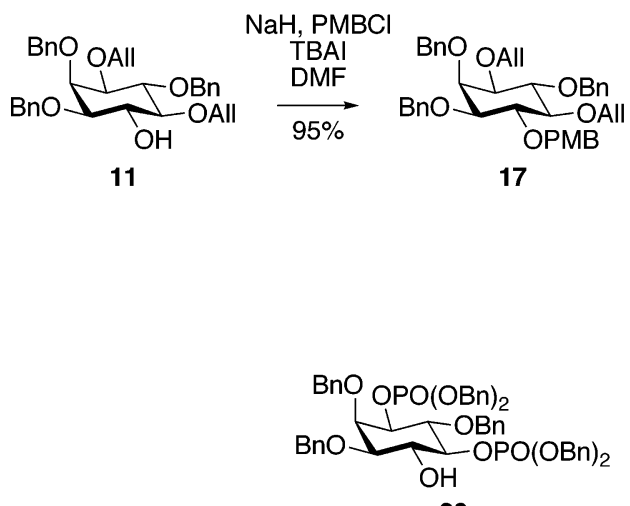

20

${ }^{a} \mathrm{CAN}=$ ammonium cerium nitrate.
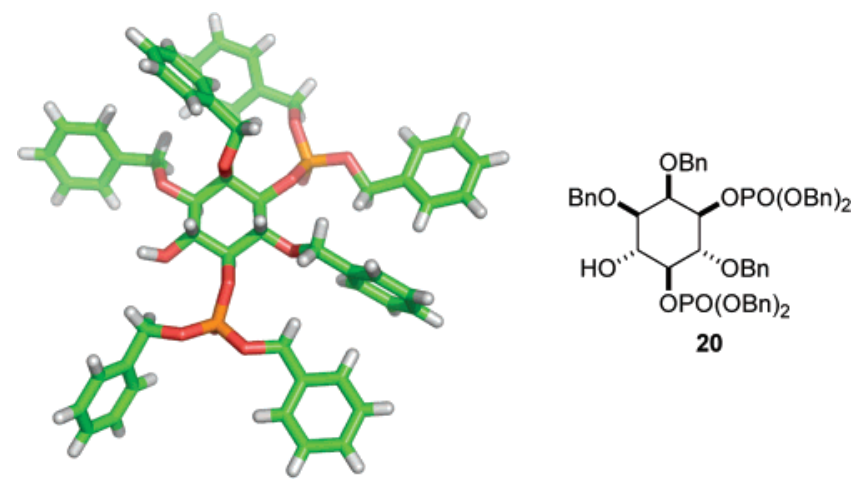

FIGURE 6. A stick representation of the X-ray crystal structure of compound 20. The absolute stereochemistry was confirmed unambiguously using the anomalous dispersion effect [Flack parameter 0.03(4)]. Key: carbon, green; hydrogen, white; oxygen, red; phosphorus, orange.

in fractional loss (as observed with $0.2 \mu \mathrm{M} \operatorname{Ins} P_{3}$ ). Furthermore, we have used L15 cells for this analysis since these L fibroblasts are a stable cell line overexpressing Ins $P_{3} \mathrm{R} 1$. They are therefore a model system for the functional analysis of Ins $P_{3} \mathrm{R} 1$. Western blot analysis of L15 cell lysates indicates a 3:1 ratio for $\operatorname{Ins} P_{3^{-}}$ $\mathrm{R} 1 /$ Ins $P_{3} \mathrm{R} 3$ (data not shown).

The compounds were first tested for their ability to evoke $\mathrm{Ca}^{2+}$ release (i.e., behave as $\operatorname{Ins} P_{3} \mathrm{R}$ agonists). None of the compounds induced an increase in fractional loss when applied for $2 \mathrm{~min}$ at a concentration of $20 \mu \mathrm{M}$ (Figure 7), indicating that these compounds do not act as $\operatorname{Ins} P_{3} \mathrm{R}$ agonists.

The compounds were then tested for their ability to block Ins $P_{3}$-evoked $\mathrm{Ca}^{2+}$ release (Figure 8). Experiments were conducted in which the compounds were applied in 100-fold excess $(20 \mu \mathrm{M})$ at the same time as Ins $P_{3}$ (data not shown) and also where the compounds were preincubated with the L15 cells for 2 min prior to application of $\operatorname{Ins} P_{3}(0.2 \mu \mathrm{M})$. In each case it can be seen that the rise in $\mathrm{Ca}^{2+}$ concentration due to the action of Ins $P_{3}$ was not abrogated by the presence of compounds 3-5, 16, and 24 (Figure 8). Compound 6 was evaluated in a separate batch of experiments and also failed to prevent Ins $P_{3}$ evoked $\mathrm{Ca}^{2+}$ release (data not shown). It can therefore be concluded that these compounds are not acting as $\operatorname{Ins} P_{3} \mathrm{R}$ antagonists.

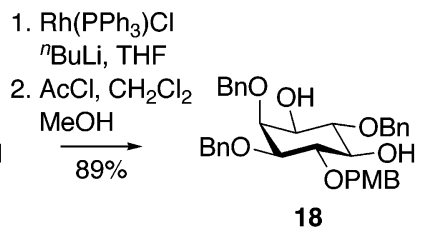

1. $(\mathrm{OBn})_{2} \mathrm{PN}^{\mathrm{P} P r}{ }_{2}$
1H-tetrazole, $\mathrm{CH}_{2} \mathrm{Cl}_{2}$
2. $\mathrm{mCPBA}, \mathrm{CH}_{2} \mathrm{Cl}_{2}$
$75 \%$

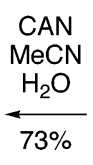

$\frac{\mathrm{H}_{2} \mathrm{O}}{73 \%}$

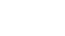

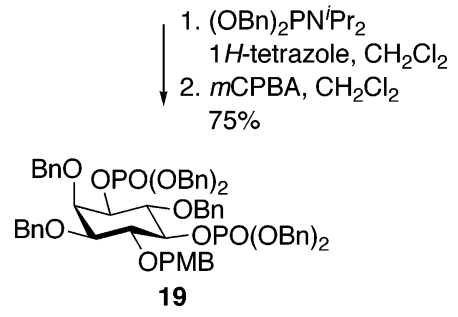

\section{Conclusion}

We have described a robust synthesis of a range of novel 4-position-modified Ins $P_{3}$ derivatives. To the best of our knowledge, these syntheses represent the first example of dialkylphosphinate incorporation within an inositol phosphatebased structure. Compound $\mathbf{6}$ is the first in a novel class of compounds in which a linker is included between the inositol ring and a phosphate (or other moiety).

Despite the compounds synthesized proving to be inactive at Ins $P_{3} \mathrm{Rs}$, a number of important conclusions concerning the structure-activity relationship can be drawn from this work. As expected, disruption of the 4,5-bisphosphate motif within the Ins $P_{3}$ structure led to the agonist activity of these compounds being abolished. However, it also seems removal of the 4-position phosphate group does not convey the ability of a compound to bind to one domain of the $\operatorname{Ins} P_{3}$ Rs without causing receptor activation. The most likely explanation for the lack of Ins $P_{3}$ affinity displayed by these compounds is that the groups installed at the 4-position were too lipophilic to enter the highly charged Ins $P_{3}$-binding pocket of the Ins $P_{3}$ Rs. We hypothesized that the "clam shell" of the Ins $P_{3}$ Rs would be mainly open in the unactivated receptor, allowing compounds with 1- and 5 -position phosphate groups to bind to the $\alpha$-domain without interacting with the $\beta$-domain. It seems that this hypothesis is not correct, and this may suggest that the two domains of the Ins $P_{3}$-binding domain do not fully open, even in the inactive conformation of the receptor. In addition, our data may indicate that the 4-position phosphate group is vital for receptor binding and recognition, rather than activation; thus, any alteration of this group removes the ability of the compound to bind to $\operatorname{Ins} P_{3^{-}}$ Rs. Future studies will seek to test these hypotheses.

\section{Experimental Section}

For general experimental methods, please see the Supporting Information.

(-)-1D-1,5-Bis- $O$-allyl-2,6-bis- $O$-benzyl-3-O-endo-4-O-exo-(L$1^{\prime}, 7^{\prime}, 7^{\prime}$-trimethylbicyclo[2.2.1]hept-2'-ylidene)-myo-inositol (9). (-)-1D-5-O-Allyl-2,6-bis-O-benzyl-3-O-endo-4-O-exo-(L-1', $7^{\prime}, 7^{\prime}$ trimethylbicyclo[2.2.1]hept-2'-ylidene)-myo-inositol (8) (2.4 g, 4.5 $\mathrm{mmol})$ was dissolved in dry tetrahydrofuran $(20 \mathrm{~mL})$ under an atmosphere of nitrogen, the resulting mixture was cooled to $0{ }^{\circ} \mathrm{C}$, and sodium hydride $(219 \mathrm{mg}, 60 \%$ dispersion in mineral oil, 5.4 mmol) was added. The resulting mixture was allowed to warm to $\mathrm{rt}$ and stirred for $1 \mathrm{~h}$. The mixture was recooled to $0{ }^{\circ} \mathrm{C}$, and 
SCHEME 4. Synthesis of the 4-Position-Modified $\operatorname{Ins} P_{3}$ Derivatives

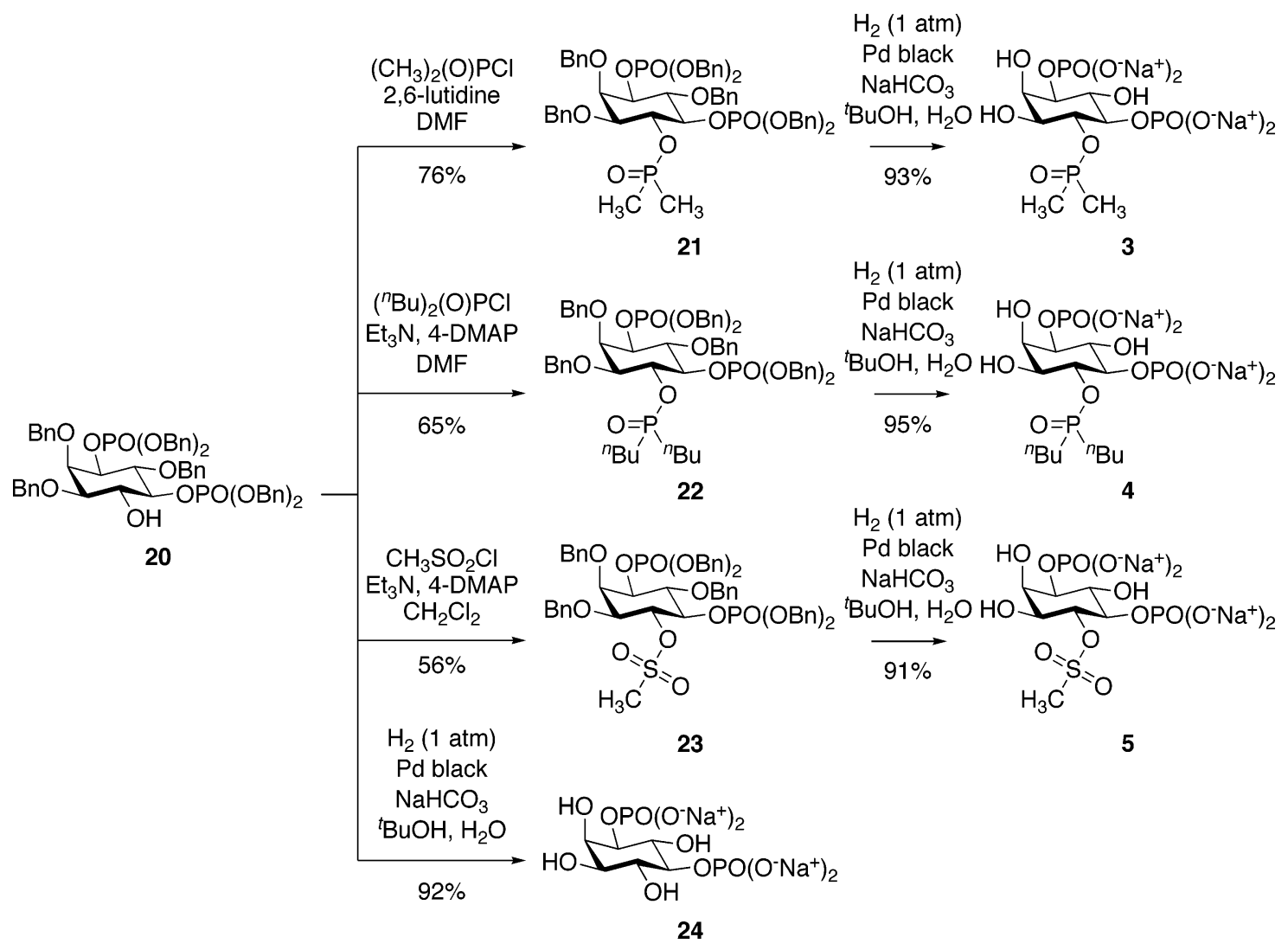

SCHEME 5. Synthesis of the Trisphosphate 6

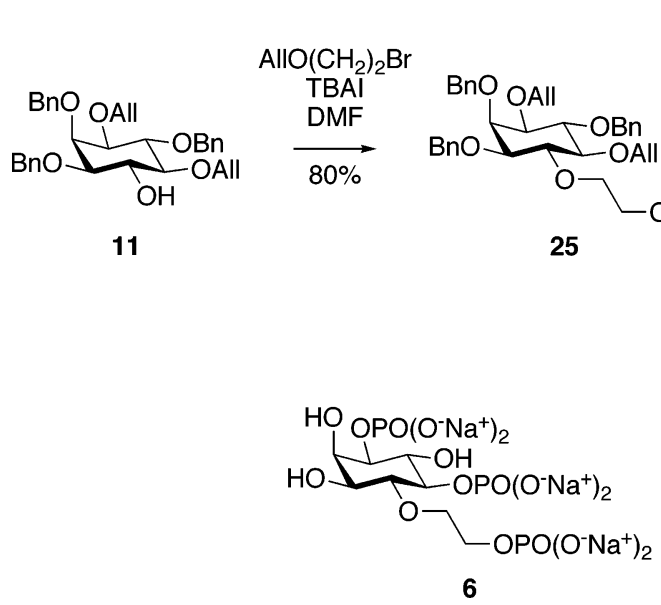

imidazole (catalytic amount) and tetra- $n$-butylammonium iodide (catalytic amount) were added, followed by allyl bromide $(653 \mathrm{mg}$, $472 \mu \mathrm{L}, 5.4 \mathrm{mmol}$ ), which was added dropwise. The reaction mixture was warmed to $\mathrm{rt}$, then dry $\mathrm{N}, \mathrm{N}$-dimethylformamide (30 $\mathrm{mL}$ ) was added, and the resulting mixture was stirred overnight. The sodium hydride was quenched with water $(2 \mathrm{~mL})$, the solvent removed under reduced pressure, and the residue reconstituted in ethyl acetate $(15 \mathrm{~mL})$ and water $(15 \mathrm{~mL})$. The layers were separated, and the aqueous layer was extracted with ethyl acetate $(3 \times 15$ $\mathrm{mL})$. The combined organic layers were washed with brine $(10$ $\mathrm{mL}$ ), dried (magnesium sulfate), filtered, and concentrated under reduced pressure to afford a yellow oil. Purification by silica gel column chromatography, eluting with ethyl acetate and petroleum ether (5:95), yielded $9(2.4 \mathrm{~g}, 91 \%)$ as a colorless solid: $R_{f} 0.45$ (ethyl acetate/petroleum ether, 20:80); $[\alpha]_{\mathrm{D}}^{26}=-23.0$ (c 0.49 in $\mathrm{CHCl}_{3}$ ); mp $55-57{ }^{\circ} \mathrm{C}$ (from ethyl acetate/petroleum ether); $v_{\text {max }}$ (KBr disk)/ $\mathrm{cm}^{-1} 3064.4$ (w), 3025.2 (w), 2932.8 (s), 2868.3 (s),

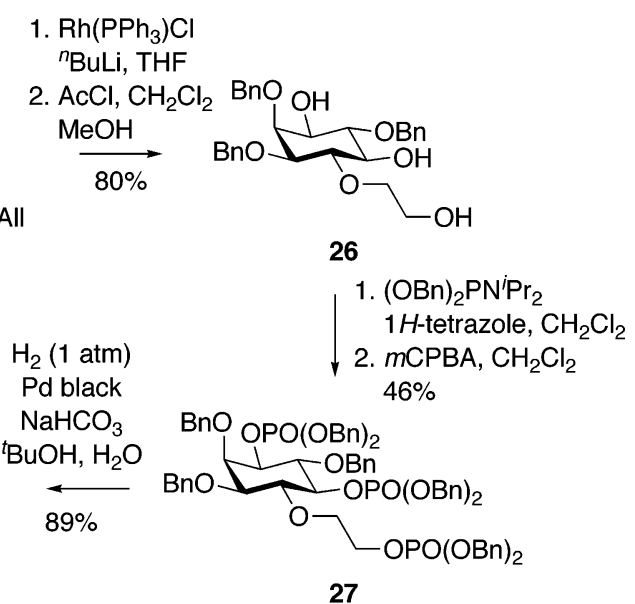

1647.6 (w), 1453.9 (m), 1366.6 (m), 1309.5 (m), 1203.4 (m), 1092.7 (s), $1048.9(\mathrm{~s}), 921.2(\mathrm{~s}), 778.2(\mathrm{w}), 747.9$ (s), 697.6 (s), 595.8 (w); ${ }^{1} \mathrm{H}$ NMR $\left(300 \mathrm{MHz}, \mathrm{CDCl}_{3}\right) \delta 7.40-7.25$ (m, 10H), 6.06$5.85(\mathrm{~m}, 2 \mathrm{H}), 5.35$ (ddt, $J=17.1,1.8,1.5 \mathrm{~Hz}, 1 \mathrm{H}), 5.30$ (ddt, $J=$ 17.4, 1.8, $1.3 \mathrm{~Hz}, 1 \mathrm{H}), 5.19$ (ddt, $J=10.2,1.8,1.3 \mathrm{~Hz}, 2 \mathrm{H}), 4.93$ $(\mathrm{d}, J=12.3 \mathrm{~Hz}, 1 \mathrm{H}), 4.88(\mathrm{~d}, J=10.5 \mathrm{~Hz}, 1 \mathrm{H}), 4.86(\mathrm{~d}, J=12.3$ $\mathrm{Hz}, 1 \mathrm{H}), 4.84(\mathrm{~d}, J=10.5 \mathrm{~Hz}, 1 \mathrm{H}), 4.40$ (ddt, $J=13.1,5.4,1.5$ $\mathrm{Hz}, 1 \mathrm{H}), 4.27-4.20,(\mathrm{~m}, 2 \mathrm{H}), 4.09-4.02(\mathrm{~m}, 3 \mathrm{H}), 3.85$ (t, $J=9.2$ $\mathrm{Hz}, 1 \mathrm{H}), 3.51(\mathrm{dd}, J=9.5,8.7 \mathrm{~Hz}, 1 \mathrm{H}), 3.42(\mathrm{dd}, J=9.7,3.0 \mathrm{~Hz}$, $1 \mathrm{H}), 3.22(\mathrm{dd}, J=9.7,1.5 \mathrm{~Hz}, 1 \mathrm{H}), 2.16(\mathrm{dt}, J=13.6,3.6 \mathrm{~Hz}$, $1 \mathrm{H}), 2.02-1.93(\mathrm{~m}, 1 \mathrm{H}), 1.77-1.71(\mathrm{~m}, 2 \mathrm{H}), 1.48-1.36(\mathrm{~m}, 2 \mathrm{H})$, 1.29-1.19 (m, 1H), 1.05 (s, 3H), 0.91 (s, 3H), $0.88(\mathrm{~s}, 3 \mathrm{H}) ;{ }^{13} \mathrm{C}$ NMR $\left(75 \mathrm{MHz}, \mathrm{CDCl}_{3}\right) \delta 139.1,138.5,135.4,134.9,128.3,128.2$, $127.9,127.55,127.5,120.4,117.1,116.4,82.8,81.2,81.0,77.2$, 76.7, 76.5, 73.3, 71.7, 71.6, 70.8, 52.9, 48.2, 46.2, 45.0, 29.0, 26.8, 20.4, 20.2, 9.7; HRMS $\mathrm{m} / \mathrm{z}\left(\mathrm{ES}^{+}\right)$[found $(\mathrm{M}+\mathrm{Na})^{+}$597.3171, 


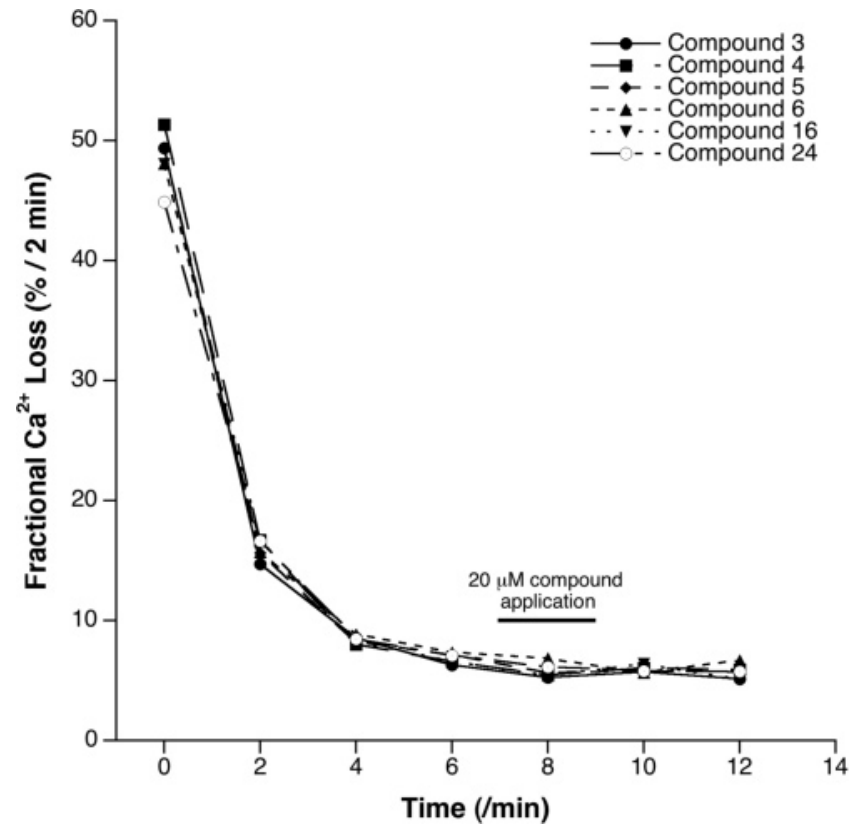

FIGURE 7. Effect of compounds 3-6, 16, and 24 on ${ }^{45} \mathrm{Ca}^{2+}$ release from permeabilized L15 cells. It can be seen that none of the compounds evoked $\mathrm{Ca}^{2+}$ release. The bold line, labeled " $20 \mu \mathrm{M}$ compound application", indicates the period of time in which a $20 \mu \mathrm{M}$ solution of each compound was applied to the cells.

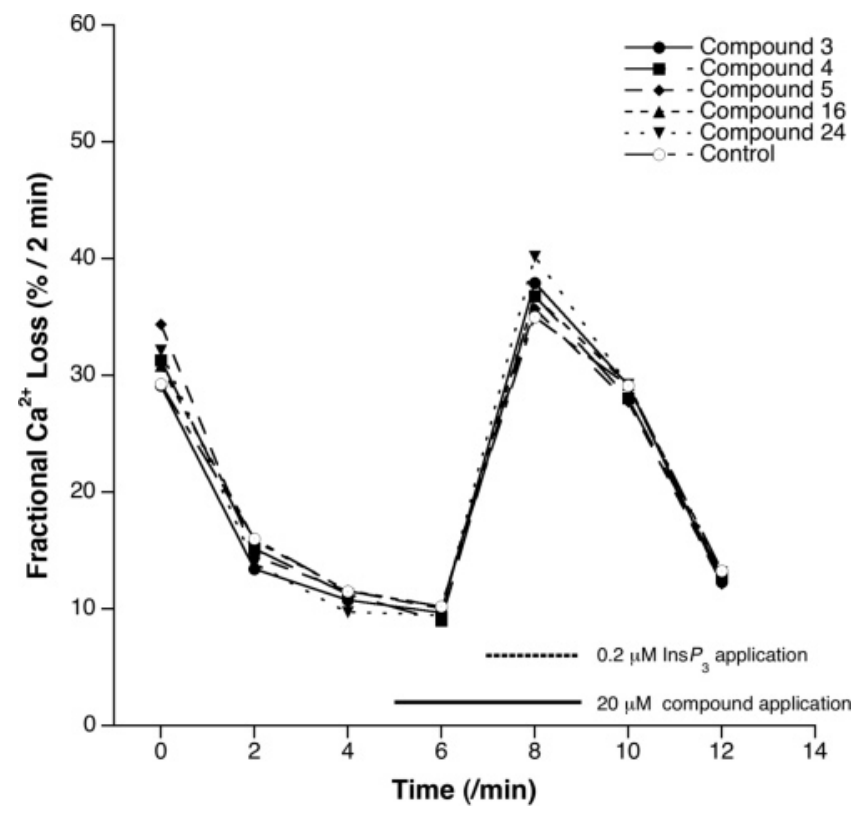

FIGURE 8. Effect of compounds 3-5, 16, and 24 on Ins $P_{3}$-evoked ${ }^{45} \mathrm{Ca}^{2+}$ release from permeabilized L15 cells. It can be seen that none of the compounds prevented Ins $P_{3}$-evoked $\mathrm{Ca}^{2+}$ release. The bold line, labeled " $20 \mu \mathrm{M}$ compound application", indicates the period of time in which a $20 \mu \mathrm{M}$ solution of each compound was applied to the cells. The bold dashed line, labeled " $0.2 \mu \mathrm{M}$ Ins $P_{3}$ application", indicates the period of time in which a $0.2 \mu \mathrm{M}$ solution of $\operatorname{Ins} P_{3}$ was applied to the cells.

$\mathrm{C}_{36} \mathrm{H}_{46} \mathrm{O}_{6} \mathrm{Na}$ requires $\left.\mathrm{M}^{+}, 597.3192\right], \mathrm{m} / \mathrm{z}\left(\mathrm{ES}^{+}\right) 597\left([\mathrm{M}+\mathrm{Na}]^{+}\right.$, 100). Anal. Calcd for $\mathrm{C}_{36} \mathrm{H}_{46} \mathrm{O}_{6}$ : C, 75.2; H, 8.1. Found: C, 75.3; H, 8.3.

(-)-1D-1,5-Bis- $O$-allyl-2,6-bis- $O$-benzyl-myo-inositol (10). 9 $(2.4 \mathrm{~g}, 4.1 \mathrm{mmol})$ was dissolved in methanol and dichloromethane $(2: 3,50 \mathrm{~mL})$ under an atmosphere of nitrogen. Acetyl chloride (194 $\mathrm{mg}, 176 \mu \mathrm{L}, 2.5 \mathrm{mmol}$ ) was added and the resulting solution stirred for $4 \mathrm{~h}$. The generated hydrochloric acid was quenched with triethylamine $(1 \mathrm{~mL})$, the solvent removed under reduced pressure, and the resulting yellow solid adsorbed onto silica and purified by silica gel column chromatography, eluting with ethyl acetate and petroleum ether (30:70), to yield $\mathbf{1 0}(1.6 \mathrm{~g}, 88 \%)$ as a colorless solid: $R_{f} 0.55$ (ethyl acetate); $[\alpha]_{\mathrm{D}}^{26}-16.8$ ( $c 0.64$ in $\left.\mathrm{CHCl}_{3}\right) ; \mathrm{mp}$ $119-120^{\circ} \mathrm{C}$ (from ethyl acetate/petroleum ether); $v_{\max }(\mathrm{KBr}$ disk)/ $\mathrm{cm}^{-1} 3405.3(\mathrm{~s}), 3066.5(\mathrm{~m}), 3034.6(\mathrm{~m}), 2910.9(\mathrm{~s}), 2862.7(\mathrm{~s})$, 1647.7 (w), $1497.4(\mathrm{~m}), 1455.7$ (s), 1425.7 (s), 1354.7 (s), 1255.6 (w), $1160.8(\mathrm{~s}), 1052.2(\mathrm{~s}), 992.8(\mathrm{~s}), 928.6(\mathrm{~s}), 724.1(\mathrm{~s}), 696.4$ (s), $576.2(\mathrm{w}), 460.1(\mathrm{w}) ;{ }^{1} \mathrm{H}$ NMR $\left(300 \mathrm{MHz}, \mathrm{CDCl}_{3}\right) \delta 7.43-$ $7.28(\mathrm{~m}, 10 \mathrm{H}), 6.05-5.90(\mathrm{~m}, 2 \mathrm{H}), 5.35(\mathrm{ddt}, J=17.1,1.8,1.5$ $\mathrm{Hz}, 1 \mathrm{H}$ ), 5.30 (ddt, $J=17.2,1.8,1.5 \mathrm{~Hz}, 1 \mathrm{H}$ ), 5.22 (ddt, $J=10.5$, $1.5,1.3 \mathrm{~Hz}, 1 \mathrm{H}), 5.14$ (ddt, $J=10.2,1.8,1.3 \mathrm{~Hz}, 1 \mathrm{H}), 5.05$ (d, $J$ $=11.8 \mathrm{~Hz}, 1 \mathrm{H}), 4.90(\mathrm{~d}, J=10.5 \mathrm{~Hz}, 1 \mathrm{H}), 4.80(\mathrm{~d}, J=10.5 \mathrm{~Hz}$, $1 \mathrm{H}), 4.70(\mathrm{~d}, J=11.8 \mathrm{~Hz}, 1 \mathrm{H}), 4.41(\mathrm{ddt}, J=12.3,5.6,1.5 \mathrm{~Hz}$, $1 \mathrm{H}), 4.28$ (ddt, $J=12.3,5.8,1.3 \mathrm{~Hz}, 1 \mathrm{H}), 4.19-4.17$, (m, 2H), $4.02(\mathrm{t}, J=2.3 \mathrm{~Hz}, 1 \mathrm{H}), 3.92(\mathrm{t}, J=9.7 \mathrm{~Hz}, 1 \mathrm{H}), 3.81(\mathrm{t}, J=9.5$ $\mathrm{Hz}, 1 \mathrm{H}), 3.42-3.34(\mathrm{~m}, 2 \mathrm{H}), 3.19$ (t, $J=9.2 \mathrm{~Hz}, 1 \mathrm{H}), 2.69$ (br s, $2 \mathrm{H}) ;{ }^{13} \mathrm{C}$ NMR $\left(75 \mathrm{MHz}, \mathrm{CDCl}_{3}\right) \delta 138.7,138.67,135.2,134.8$, $128.4,128.3,128.2,127.8,127.7,127.6,117.0,116.9,82.6,81.4$, 81.0, 77.2, 75.8, 74.8, 74.2, 73.8, 72.1, 71.9; HRMS m/z $\left(\mathrm{ES}^{+}\right)$ [found $(\mathrm{M}+\mathrm{Na})^{+} 463.2088, \mathrm{C}_{26} \mathrm{H}_{32} \mathrm{O}_{6} \mathrm{Na}$ requires $\mathrm{M}^{+}$, 463.2097], $m / z\left(\mathrm{ES}^{+}\right) 463\left([\mathrm{M}+\mathrm{Na}]^{+}, 100\right)$. Anal. Calcd for $\mathrm{C}_{26} \mathrm{H}_{32} \mathrm{O}_{6}: \mathrm{C}$, 70.9; H, 7.3. Found: C, 70.6; H, 7.6.

(+)-1D-1,5-Bis- $O$-Allyl-2,3,6-tris- $O$-benzyl-myo-inositol (11). $10(2.0 \mathrm{~g}, 4.5 \mathrm{mmol})$, di- $n$-butyltin oxide $(1.2 \mathrm{~g}, 5.0 \mathrm{mmol})$, tetran-butylammonium iodide (1.9 g, $4.5 \mathrm{mmol})$, and benzyl bromide $(3.7 \mathrm{~g}, 2.6 \mathrm{~mL}, 21.8 \mathrm{mmol})$ were dissolved in acetonitrile $(80 \mathrm{~mL})$ under an atmosphere of nitrogen. The mixture was heated under reflux for $24 \mathrm{~h}$ using a Soxhlet apparatus filled with $3 \AA$ molecular sieves to remove water generated in the reaction. The reaction mixture was cooled to $\mathrm{rt}$, and the solvent was removed under reduced pressure. The residue was reconstituted in ethyl acetate $(20 \mathrm{~mL})$ and water $(20 \mathrm{~mL})$, the layers were separated, and the aqueous layer was extracted with ethyl acetate $(3 \times 20 \mathrm{~mL})$. The combined organic layers were washed with a saturated aqueous solution of sodium hydrogen carbonate $(20 \mathrm{~mL})$, and the resulting solid was removed by filtration through Celite. The filtrate was washed with brine $(20 \mathrm{~mL})$, dried (magnesium sulfate), filtered, and concentrated under reduced pressure to yield a yellow residue. Purification by activated aluminum oxide column chromatography (twice), eluting with ethyl acetate and petroleum ether (50:50), yielded $\mathbf{1 1}(1.7 \mathrm{~g}, 71 \%)$ as a colorless solid: $R_{f} 0.23$ (ethyl acetate/ petroleum ether, 30:70); $[\alpha]_{\mathrm{D}}^{26}+2.8\left(c 0.68\right.$ in $\left.\mathrm{CHCl}_{3}\right)$; mp 69-71 ${ }^{\circ} \mathrm{C}$ (from diethyl ether/petroleum ether); $v_{\max }\left(\mathrm{KBr}\right.$ disk) $/ \mathrm{cm}^{-1}$ $3530.9(\mathrm{~s}), 3258.2(\mathrm{~s}), 3064.2(\mathrm{~m}), 3030.1(\mathrm{~m}), 2893.6(\mathrm{~s}), 2862.7$ (s), $1648.1(\mathrm{w}), 1497.5(\mathrm{~m}), 1454.3(\mathrm{~s}), 1350.9(\mathrm{~s}), 1210.4(\mathrm{w})$, $1128.6(\mathrm{~s}), 1069.3(\mathrm{~s}), 1027.2(\mathrm{~s}), 929.6(\mathrm{~m}), 928.6(\mathrm{~s}), 755.2(\mathrm{w})$, 728.6 (s), 695.4 (s), 565.0 (w); ${ }^{1} \mathrm{H}$ NMR $\left(300 \mathrm{MHz}, \mathrm{CDCl}_{3}\right) \delta$ $7.44-7.25(\mathrm{~m}, 15 \mathrm{H}), 6.06-5.87(\mathrm{~m}, 2 \mathrm{H}), 5.33$ (ddt, $J=17.2,1.8$, $1.5 \mathrm{~Hz}, 1 \mathrm{H}), 5.30$ (ddt, $J=17.4,1.8,1.5 \mathrm{~Hz}, 1 \mathrm{H}), 5.20$ (ddt, $J=$ $10.5,1.5,1.3 \mathrm{~Hz}, 1 \mathrm{H}), 5.18$ (ddt, $J=10.2,1.8,1.5 \mathrm{~Hz}, 1 \mathrm{H}), 4.90$ $(\mathrm{d}, J=12.0 \mathrm{~Hz}, 1 \mathrm{H}), 4.89(\mathrm{~d}, J=10.5 \mathrm{~Hz}, 1 \mathrm{H}), 4.82-4.78(\mathrm{~m}$, $2 \mathrm{H}), 4.63(\mathrm{~d}, J=11.8 \mathrm{~Hz}, 1 \mathrm{H}), 4.57(\mathrm{~d}, J=11.8 \mathrm{~Hz}, 1 \mathrm{H}), 4.43-$ $4.30(\mathrm{~m}, 2 \mathrm{H}), 4.16-4.09(\mathrm{~m}, 3 \mathrm{H}), 4.05(\mathrm{t}, J=2.3 \mathrm{~Hz}, 1 \mathrm{H}), 4.00$ $(\mathrm{t}, J=9.5 \mathrm{~Hz}, 1 \mathrm{H}), 3.29-3.18(\mathrm{~m}, 3 \mathrm{H}), 2.55(\mathrm{br} \mathrm{s}, 1 \mathrm{H}) ;{ }^{13} \mathrm{C} \mathrm{NMR}$ $\left(75 \mathrm{MHz}, \mathrm{CDCl}_{3}\right) \delta 139.3,138.4,135.8,135.3,128.9,128.8,128.6$, $128.3,128.2,128.1,128.0,127.8,117.2,83.3,81.8,81.3,80.5$, 76.3, 74.6, 74.4, 74.0, 73.1, 72.8, $72.2(\mathrm{~s})$; HRMS $\mathrm{m} / \mathrm{z}\left(\mathrm{ES}^{+}\right.$) [found $(\mathrm{M}+\mathrm{Na})^{+}$553.2563, $\mathrm{C}_{33} \mathrm{H}_{38} \mathrm{O}_{6} \mathrm{Na}$ requires $\left.\mathrm{M}^{+}, 553.2566\right], \mathrm{m} / \mathrm{z}$ $\left(\mathrm{ES}^{+}\right) 553\left([\mathrm{M}+\mathrm{Na}]^{+}, 100\right)$. Anal. Calcd for $\mathrm{C}_{33} \mathrm{H}_{38} \mathrm{O}_{6}: \mathrm{C}, 74.7$; $\mathrm{H}, 7.2$. Found: $\mathrm{C}, 74.5 ; \mathrm{H}, 7.3$.

$(-)-1 \mathrm{D}-1,5$-Bis- $O$-allyl-2,3,6-tris- $O$-benzyl-4- $O$-(dimethylphosphinyl)-myo-inositol (12). (Diisopropylamino)dimethylphosphine (76 mg, $471 \mu \mathrm{mol})$ and $1 H$-tetrazole $(0.43 \mathrm{M}$ solution in acetonitrile, $1.1 \mathrm{~mL}, 471 \mu \mathrm{mol})$ were dissolved in dry dichloromethane $(3 \mathrm{~mL})$, 
the resulting mixture was cooled to $-78{ }^{\circ} \mathrm{C}$, and $\mathbf{1 1}(100 \mathrm{mg}, 188$ $\mu \mathrm{mol})$ dissolved in dry dichloromethane $(2 \mathrm{~mL})$ was added by cannula. The resulting mixture was allowed to warm to rt and stirred overnight. ${ }^{31} \mathrm{P} \mathrm{NMR}$ analysis indicated the complete conversion of (diisopropylamino)dimethylphosphine in the intermediate phosphinite $\left(\delta_{\mathrm{P}} 130.0\right)$. The mixture was recooled to $-78{ }^{\circ} \mathrm{C}, 3$-chloroperoxybenzoic acid $(60 \%(\mathrm{w} / \mathrm{w}), 112 \mathrm{mg}, 471 \mu \mathrm{mol})$ was added, and the resulting mixture was warmed to rt and stirred for $30 \mathrm{~min}$. The 3 -chloroperoxybenzoic acid was quenched with a $10 \%$ aqueous solution of sodium hydrogen sulfite $(5 \mathrm{~mL})$, the layers were separated, and the aqueous layer was extracted with dichloromethane $(3 \times 5 \mathrm{~mL})$. The combined organic layers were washed with a $10 \%$ aqueous solution of sodium hydrogen bicarbonate ( 5 $\mathrm{mL}$ ) and brine $(5 \mathrm{~mL})$, dried (magnesium sulfate), filtered, and concentrated under reduced pressure. Purification by silica gel column chromatography, eluting with methanol and ethyl acetate (2:98), yielded 12 (107 mg, 94\%) as a colorless solid. Further purification was achieved by crystallization from diethyl ether/ dichloromethane/petroleum ether: $R_{f} 0.38$ (ethyl acetate); $[\alpha]_{\mathrm{D}}^{26}$ -1.9 (c 0.27 in $\mathrm{CHCl}_{3}$ ); $\mathrm{mp} 122-124{ }^{\circ} \mathrm{C}$ (from diethyl ether/ dichloromethane/petroleum ether); $v_{\max }\left(\mathrm{KBr}\right.$ disk) $/ \mathrm{cm}^{-1} 3064.3(\mathrm{w})$, 3031.7 (w), 2823.2 (s), 2851.5 (s), 1454.5 (m), 1302.9 (m), 1216.5 (s), $1130.6(\mathrm{~m}), 1096.4(\mathrm{~s}), 1050.2(\mathrm{~s}), 935.2(\mathrm{~s}), 866.9(\mathrm{~m}), 736.2$ (s), $698.9(\mathrm{w}) ;{ }^{1} \mathrm{H}$ NMR $\left(300 \mathrm{MHz}, \mathrm{CDCl}_{3}\right) \delta 7.41-7.28(\mathrm{~m}, 15 \mathrm{H})$, $6.04-5.83(\mathrm{~m}, 2 \mathrm{H}), 5.33-5.25(\mathrm{~m}, 2 \mathrm{H}), 5.18(\mathrm{ddt}, J=10.5,1.8$, $1.5 \mathrm{~Hz}, 1 \mathrm{H}), 5.15$ (ddt, $J=10.2,1.5,1.3 \mathrm{~Hz}, 1 \mathrm{H}), 4.88-4.74(\mathrm{~m}$, $4 \mathrm{H}), 4.66-4.54(\mathrm{~m}, 3 \mathrm{H}), 4.39$ (ddt, $J=12.3,5.6,1.5 \mathrm{~Hz}, 1 \mathrm{H})$, 4.27 (ddt, $J=12.3,5.6,1.5 \mathrm{~Hz}, 1 \mathrm{H}), 4.13-4.05(\mathrm{~m}, 2 \mathrm{H}), 4.00-$ $3.94(\mathrm{~m}, 2 \mathrm{H}), 3.33-3.29(\mathrm{~m}, 2 \mathrm{H}), 3.24(\mathrm{dd}, J=9.8,2.1 \mathrm{~Hz}, 1 \mathrm{H})$, $1.50(\mathrm{~d}, J=14.1 \mathrm{~Hz}, 3 \mathrm{H}), 1.49(\mathrm{~d}, J=14.1 \mathrm{~Hz}, 3 \mathrm{H}) ;{ }^{13} \mathrm{C} \mathrm{NMR}$ $\left(75 \mathrm{MHz}, \mathrm{CDCl}_{3}\right) \delta 139.1,139.0,138.0,135.3,135.1,128.9,128.9$, $128.8,128.6,128.4,128.3,128.2,128.1,127.9,117.3,117.1,81.9$ $(\mathrm{d}, J=2.8 \mathrm{~Hz}), 81.7,80.7,79.4(\mathrm{~d}, J=2.2 \mathrm{~Hz}), 76.6,(\mathrm{~d}, J=8.3$ Hz), 76.3, 74.7, 74.6, 73.9, 73.0, 72.1, 17.0 (d, $J=94.0 \mathrm{~Hz}), 16.9$ $(\mathrm{d}, J=94.0 \mathrm{~Hz}) ;{ }^{31} \mathrm{P}$ NMR $\left(121 \mathrm{MHz}, \mathrm{CDCl}_{3}\right) \delta 54.8$; HRMS $\mathrm{m} / z$ $\left(\mathrm{ES}^{+}\right)$[found $(\mathrm{M}+\mathrm{Na})^{+} 629.2643, \mathrm{C}_{35} \mathrm{H}_{43} \mathrm{O}_{7} \mathrm{NaP}$ requires $\mathrm{M}^{+}$, 629.2644], $\mathrm{m} / \mathrm{z}\left(\mathrm{ES}^{+}\right) 629\left([\mathrm{M}+\mathrm{Na}]^{+}, 100\right)$. Anal. Calcd for $\mathrm{C}_{35} \mathrm{H}_{43} \mathrm{O}_{7} \mathrm{P}:$ C, 69.3; H, 7.1. Found: C, 69.3; H, 7.2.

(-)-1D-1,5-Bis- $O$-allyl-2,3,6-tris- $O$-benzyl-4- $O$-methyl-myoinositol (13). $11(150 \mathrm{mg}, 283 \mu \mathrm{mol})$ was dissolved in dry tetrahydrofuran $(8 \mathrm{~mL})$ under an atmosphere of nitrogen, the solution was cooled to $0{ }^{\circ} \mathrm{C}$, and sodium hydride $(13 \mathrm{mg}, 60 \%$ dispersion in mineral oil, $311 \mu \mathrm{mol}$ ) was added. The mixture was allowed to warm to rt and stirred for $2 \mathrm{~h}$, then it was recooled to $0{ }^{\circ} \mathrm{C}$, and methyl iodide ( $44 \mathrm{mg}, 19 \mu \mathrm{L}, 311 \mu \mathrm{mol}$ ) was added. The mixture was warmed to $\mathrm{rt}$ and stirred overnight. The sodium hydride was quenched with water $(1 \mathrm{~mL})$, the solvent removed under reduced pressure, and the residue reconstituted in ethyl acetate $(10 \mathrm{~mL})$ and water $(10 \mathrm{~mL})$. The layers were separated, and the aqueous layer was extracted with ethyl acetate $(3 \times 10 \mathrm{~mL})$. The combined organic layers were washed with brine $(10 \mathrm{~mL})$, dried (magnesium sulfate), filtered, and concentrated under reduced pressure. Purification by silica gel column chromatography, eluting with ethyl acetate and petroleum ether (10:90), yielded 13 (184 $\mathrm{mg}, 92 \%$ ) as a colorless waxy solid: $R_{f} 0.70$ (ethyl acetate/ petroleum ether, 30:70); $\mathrm{mp} 35-36{ }^{\circ} \mathrm{C}$ (from ethyl acetate/ petroleum ether); $[\alpha]_{\mathrm{D}}^{26}-4.05\left(c 0.41\right.$ in $\left.\mathrm{CHCl}_{3}\right) ; v_{\max }(\mathrm{KBr}$ disk $) /$ $\mathrm{cm}^{-1} 3064.6(\mathrm{w}), 3030.5(\mathrm{w}), 2925.6(\mathrm{~m}), 1647.5(\mathrm{w}), 1496.9(\mathrm{~m})$, $1454.8(\mathrm{~m}), 1357.4(\mathrm{~m}), 1207.7(\mathrm{w}), 1132.9(\mathrm{~s}), 1088.2(\mathrm{~s}), 1028.3$ (m), $995.6(\mathrm{w}), 924.5(\mathrm{~m}), 734.9(\mathrm{~m}), 697.2(\mathrm{~m}) ;{ }^{1} \mathrm{H}$ NMR (300 $\left.\mathrm{MHz}, \mathrm{CDCl}_{3}\right) \delta 7.36-7.16(\mathrm{~m}, 15 \mathrm{H}), 5.98-5.76(\mathrm{~m}, 2 \mathrm{H}), 5.26-$ $5.18(\mathrm{~m}, 2 \mathrm{H}), 5.11-5.06(\mathrm{~m}, 2 \mathrm{H}), 4.79(\mathrm{~s}, 2 \mathrm{H}), 4.78(\mathrm{~d}, J=10.5$ $\mathrm{Hz}, 1 \mathrm{H}), 4.70(\mathrm{~d}, J=10.5 \mathrm{~Hz}, 1 \mathrm{H}), 4.61(\mathrm{~d}, J=11.8 \mathrm{~Hz}, 1 \mathrm{H})$ $4.51(\mathrm{~d}, J=11.8 \mathrm{~Hz}, 1 \mathrm{H}), 4.25(\mathrm{dt}, J=5.6,1.3 \mathrm{~Hz}, 2 \mathrm{H}), 4.02-$ $3.98(\mathrm{~m}, 2 \mathrm{H}), 3.90(\mathrm{t}, J=2.3 \mathrm{~Hz}, 1 \mathrm{H}), 3.85(\mathrm{t}, J=9.4 \mathrm{~Hz}, 1 \mathrm{H})$, $3.64(\mathrm{t}, J=9.7 \mathrm{~Hz}, 1 \mathrm{H}), 3.58(\mathrm{~s}, 3 \mathrm{H}), 3.17-3.09(\mathrm{~m}, 3 \mathrm{H}) ;{ }^{13} \mathrm{C}$ NMR $\left(75 \mathrm{MHz}, \mathrm{CDCl}_{3}\right) \delta 139.4,139.3,139.1,135.9,135.4,128.8$, $128.76,128.7,128.5,128.2,128.01,128.0,127.8,127.7,117.1$, 116.9, 84.0, 83.9, 81.9, 81.1, 80.9, 76.3, 75.0, 74.8, 74.4, 73.2, 72.8,
61.8; HRMS $m / z\left(\mathrm{ES}^{+}\right)$[found $(\mathrm{M}+\mathrm{Na})^{+} 567.2716, \mathrm{C}_{34} \mathrm{H}_{40} \mathrm{O}_{6} \mathrm{Na}$ requires $\left.\mathrm{M}^{+}, 567.2723\right], \mathrm{m} / \mathrm{z}\left(\mathrm{ES}^{+}\right) 567\left([\mathrm{M}+\mathrm{Na}]^{+}, 100\right)$. Anal. Calcd for $\mathrm{C}_{34} \mathrm{H}_{40} \mathrm{O}_{6}$ : C, 75.0; H, 7.4. Found: C, 75.2; H, 7.4.

(+)-1D-2,3,6-Tris- $O$-benzyl-4- $O$-methyl-myo-inositol (14). 13 ( $80 \mathrm{mg}, 147 \mu \mathrm{mol})$, Wilkinson's catalyst (41 mg, $44 \mu \mathrm{mol}$ ), and Hunig's base ( $38 \mathrm{mg}, 51 \mu \mathrm{L}, 294 \mu \mathrm{mol})$ were suspended in ethanol $(8 \mathrm{~mL})$, and the resulting mixture was heated under reflux for $3 \mathrm{~h}$. The mixture was then cooled to $0{ }^{\circ} \mathrm{C}$ and filtered through Celite and the filtrate concentrated under reduced pressure. The resulting red residue was dissolved in methanol and dichloromethane $(2: 3$, $8 \mathrm{~mL}$ ), acetyl chloride ( $7 \mathrm{mg}, 6 \mu \mathrm{L}, 88 \mu \mathrm{mol}$ ) was added, and the mixture was stirred for $2 \mathrm{~h}$. The generated hydrochloric acid was quenched with triethylamine $(1 \mathrm{~mL})$, the solvent was removed under reduced pressure, the residue was reconstituted in ethyl acetate (5 $\mathrm{mL})$ and water $(5 \mathrm{~mL})$, the layers were separated, and the aqueous layer was extracted with ethyl acetate $(3 \times 5 \mathrm{~mL})$. The combined organic layers were washed with a saturated aqueous solution of sodium hydrogen carbonate $(5 \mathrm{~mL})$ and brine $(5 \mathrm{~mL})$, dried (magnesium sulfate), filtered, and concentrated under reduced pressure. Purification by silica gel column chromatography (twice), eluting with ethyl acetate and petroleum ether (30:70), yielded 14 (54 mg, $79 \%$ ) as a colorless solid: $R_{f} 0.5$ (ethyl acetate/petroleum ether, 50:50); $\mathrm{mp} 80-81^{\circ} \mathrm{C}$ (from ethyl acetate/petroleum ether); $[\alpha]_{\mathrm{D}}^{25}+2.1\left(c 0.45\right.$ in $\left.\mathrm{CHCl}_{3}\right) ; v_{\max }(\mathrm{KBr}$ disk $) / \mathrm{cm}^{-1} 3474.9$ (s), $3032.1(\mathrm{w}), 2914.8(\mathrm{~m}), 1719.3(\mathrm{w}), 1605.0(\mathrm{w}), 1496.9(\mathrm{~m}), 1454.8$ (m), $1357.7(\mathrm{~m}), 1206.2(\mathrm{w}), 1119.6(\mathrm{~s}), 1070.8(\mathrm{~s}), 1027.4(\mathrm{~s})$, $934.3(\mathrm{w}), 869.9(\mathrm{w}), 727.0(\mathrm{~s}), 696.2(\mathrm{~s}), 572.0(\mathrm{w}), 518.1(\mathrm{w})$; ${ }^{1} \mathrm{H}$ NMR $\left(300 \mathrm{MHz}, \mathrm{CDCl}_{3}\right) \delta 7.41-7.29(\mathrm{~m}, 15 \mathrm{H}), 4.99(\mathrm{~d}, J=$ $11.5 \mathrm{~Hz}, 1 \mathrm{H}), 4.90(\mathrm{~d}, J=11.5 \mathrm{~Hz}, 1 \mathrm{H}), 4.82(\mathrm{~d}, J=11.5 \mathrm{~Hz}$, $1 \mathrm{H}), 4.71(\mathrm{~d}, J=11.5 \mathrm{~Hz}, 1 \mathrm{H}), 4.67(\mathrm{~s}, 2 \mathrm{H}), 4.03(\mathrm{t}, J=2.3 \mathrm{~Hz}$, $1 \mathrm{H}), 3.71-3.59(\mathrm{~m}, 5 \mathrm{H}), 3.47(\mathrm{dd}, J=9.5,2.8 \mathrm{~Hz}, 1 \mathrm{H}), 3.44(\mathrm{t}$, $J=9.0 \mathrm{~Hz}, 1 \mathrm{H}), 3.36(\mathrm{dd}, J=9.7,2.3 \mathrm{~Hz}, 1 \mathrm{H}), 2.30($ br s, $2 \mathrm{H})$; ${ }^{13} \mathrm{C}$ NMR $\left(75 \mathrm{MHz}, \mathrm{CDCl}_{3}\right) \delta 138.7,138.6,138.2,128.6,128.5$, $128.4,128.1,127.8,127.7,127.7,127.7,127.5,82.9,81.7,80.8$, 77.2, 75.0, 74.9, 74.7, 72.6, 72.2, 61.4; HRMS m/z $\left(\mathrm{ES}^{+}\right)$[found $(\mathrm{M}+\mathrm{Na})^{+}$487.2088, $\mathrm{C}_{28} \mathrm{H}_{32} \mathrm{O}_{6} \mathrm{Na}$ requires $\left.\mathrm{M}^{+}, 487.2097\right], \mathrm{m} / \mathrm{z}$ $\left(\mathrm{ES}^{+}\right) 487\left([\mathrm{M}+\mathrm{Na}]^{+}, 100\right)$. Anal. Calcd for $\mathrm{C}_{28} \mathrm{H}_{32} \mathrm{O}_{6}$ : C, 72.4; $\mathrm{H}, 6.9$. Found: $\mathrm{C}, 72.5 ; \mathrm{H}, 6.9$.

(+)-1D-2,3,6-Tris- $O$-benzyl-4- $O$-methyl-myo-inositol 1,5-Bis(dibenzyl phosphate) (15). Bis(benzyloxy)( $N, N$-diisopropylamino)phosphine (353 mg, $1.0 \mathrm{mmol})$ was stirred with $1 H$-tetrazole $(0.43$ M solution in acetonitrile, $2.4 \mathrm{~mL}, 1.0 \mathrm{mmol}$ ) for $30 \mathrm{~min}$ under an atmosphere of nitrogen. 14 (95 mg, $204 \mu \mathrm{mol})$ dissolved in dry dichloromethane $(8 \mathrm{~mL})$ was added by cannula and the resulting solution stirred overnight. The solution was cooled to $-78^{\circ} \mathrm{C}$, and 3-chloroperoxybenzoic acid (176 mg, $1.0 \mathrm{mmol})$ was added. The resulting mixture was allowed to warm to rt and stirred for $30 \mathrm{~min}$. The 3-chloroperoxybenzoic acid was quenched with a $10 \%$ aqueous solution of sodium hydrogen sulfite $(5 \mathrm{~mL})$. The layers were separated, and the aqueous layer was extracted with dichloromethane $(3 \times 10 \mathrm{~mL})$. The combined organic layers were washed with a saturated aqueous solution of sodium hydrogen carbonate $(5 \mathrm{~mL})$ and brine $(5 \mathrm{~mL})$, dried (magnesium sulfate), filtered, and concentrated under reduced pressure. Purification by silica gel column chromatography, eluting with ethyl acetate and petroleum ether (30:70, then 40:60, then 50:50), yielded $15(132 \mathrm{mg}, 66 \%)$ as a colorless gum: $R_{f} 0.37$ (ethyl acetate/petroleum ether, 50:50); $[\alpha]_{\mathrm{D}}^{25}+7.6\left(c 0.2\right.$ in $\left.\mathrm{CHCl}_{3}\right) ; v_{\max }$ (thin film) $/ \mathrm{cm}^{-1} 3064.4(\mathrm{w})$, $3033.3(\mathrm{w}), 2933.0(\mathrm{~m}), 1497.5(\mathrm{~m}), 1455.5(\mathrm{~s}), 1379.8(\mathrm{~m}), 1269.5$ (s), $1214.3(\mathrm{~m}), 1124.9(\mathrm{~m}), 1091.8(\mathrm{~s}), 1013.9$ (s), 881.1 (m), 800.0 (w), 736.5 (s), 696.6 (s); ${ }^{1} \mathrm{H}$ NMR $\left(300 \mathrm{MHz}, \mathrm{CDCl}_{3}\right) \delta 7.31-$ $7.00(\mathrm{~m}, 35 \mathrm{H}), 4.96-4.62(\mathrm{~m}, 12 \mathrm{H}), 4.48(\mathrm{~s}, 2 \mathrm{H}), 4.35-4.24(\mathrm{~m}$, $2 \mathrm{H}), 4.18-4.12(\mathrm{~m}, 1 \mathrm{H}), 3.98(\mathrm{t}, J=9.4 \mathrm{~Hz}, 1 \mathrm{H}), 3.68(\mathrm{t}, J=9.4$ $\mathrm{Hz}, 1 \mathrm{H}), 3.45(\mathrm{~s}, 3 \mathrm{H}), 3.25(\mathrm{dd}, J=9.7,2.3 \mathrm{~Hz}, 1 \mathrm{H}) ;{ }^{13} \mathrm{C} \mathrm{NMR}$ $\left(75 \mathrm{MHz}, \mathrm{CDCl}_{3}\right) \delta 139.0,138.6,138.3,136.6(\mathrm{~d}, J=7.8 \mathrm{~Hz})$, $136.4(\mathrm{~d}, J=7.8 \mathrm{~Hz}), 136.1(\mathrm{~d}, J=1.7 \mathrm{~Hz}), 136.0(\mathrm{~d}, J=1.7$ Hz), 129.0, 128.95, 128.9, 128.86, 128.8, 128.7, 128.6, 128.3, 128.2, $128.1,128.02,128.0,127.93,127.9,127.8,127.7,81.4(\mathrm{~d}, J=1.7$ $\mathrm{Hz}), 80.6(\mathrm{dd}, J=6.9,1.6 \mathrm{~Hz}), 80.3,78.7(\mathrm{dd}, J=7.7,4.5 \mathrm{~Hz})$, 
$78.4(\mathrm{~d}, J=5.5 \mathrm{~Hz}), 76.4,75.5,75.1,73.3,69.9(\mathrm{~d}, J=5.6 \mathrm{~Hz})$, $69.7(\mathrm{~d}, J=5.4 \mathrm{~Hz}), 69.5(\mathrm{~d}, J=5.3 \mathrm{~Hz}), 69.4(\mathrm{~d}, J=5.2 \mathrm{~Hz})$, 61.5; ${ }^{31} \mathrm{P}$ NMR $\left(121 \mathrm{MHz}, \mathrm{CDCl}_{3}\right) \delta 0.15,-0.56$; $\mathrm{HRMS} \mathrm{m} / z\left(\mathrm{ES}^{+}\right)$ [found $(\mathrm{M}+\mathrm{Na})^{+} 1007.3288, \mathrm{C}_{56} \mathrm{H}_{58} \mathrm{O}_{12} \mathrm{NaP}_{2}$ requires $\mathrm{M}^{+}$, 1007.3301], $\mathrm{m} / \mathrm{z}\left(\mathrm{ES}^{+}\right) 1007\left([\mathrm{M}+\mathrm{Na}]^{+}, 100\right)$. Anal. Calcd for $\mathrm{C}_{56} \mathrm{H}_{58} \mathrm{O}_{12} \mathrm{P}_{2}$ : C, 68.3; H, 5.9. Found: C, 68.25; H, 5.8.

(-)-1D-4-O-Methyl-myo-inositol 1,5-Bisphosphate (Sodium Salt) (16). $15(11 \mathrm{mg}, 11 \mu \mathrm{mol})$ was dissolved in tert-butyl alcohol and water $(6: 1,3.5 \mathrm{~mL})$. Sodium hydrogen carbonate $(4 \mathrm{mg}, 43$ $\mu \mathrm{mol})$ and palladium black ( $23 \mathrm{mg}, 213 \mu \mathrm{mol})$ were added, and the flask was flushed three times with a balloon of hydrogen and then stirred for $4 \mathrm{~h}$ at $\mathrm{rt}$ under an atmosphere of hydrogen. The organic layer was removed by filtration, the dark residue washed with water $(3 \mathrm{~mL})$, and the collected aqueous layer lyophilized to yield 16 as a colorless solid $(4 \mathrm{mg}, 82 \%)$ : $[\alpha]_{\mathrm{D}}^{22}-4.6(c 0.2$ in $\left.\mathrm{H}_{2} \mathrm{O}\right) ; v_{\max }\left(\mathrm{KBr}\right.$ disk) $/ \mathrm{cm}^{-1} 3423.1$ (s), 1686.1 (s), 1650.3 (w), 1384.5 (s), 1205.6 (w), 1133.8 (s), 1085.3 (s), 1029.4 (s), 973.2 (s), $917.5(\mathrm{w}), 804.9(\mathrm{~m}), 724.8(\mathrm{~m}), 595.8(\mathrm{w}), 551.6(\mathrm{~m}) ;{ }^{1} \mathrm{H}$ NMR (300 MHz, $\left.\mathrm{D}_{2} \mathrm{O}\right) \delta 4.10$ (br s, $\left.1 \mathrm{H}\right), 3.74-3.65$ (m, 3H), 3.45-3.39 $(\mathrm{m}, 4 \mathrm{H}), 3.23(\mathrm{dd}, J=10.2,8.5 \mathrm{~Hz}, 1 \mathrm{H}) ;{ }^{13} \mathrm{C}$ NMR $(75 \mathrm{MHz}$, $\left.\mathrm{D}_{2} \mathrm{O}\right) \delta 81.3(\mathrm{~d}, J=5.5 \mathrm{~Hz}), 78.0(\mathrm{dd}, J=6.1,1.1 \mathrm{~Hz}), 74.6(\mathrm{~d}$, $J=5.5 \mathrm{~Hz}), 72.2(\mathrm{~d}, J=6.1 \mathrm{~Hz}), 70.9(\mathrm{~d}, J=1.1 \mathrm{~Hz}), 69.6(\mathrm{~d}$, $J=1.7 \mathrm{~Hz}), 60.2 ;{ }^{31} \mathrm{P}$ NMR $\left(121 \mathrm{MHz}, \mathrm{D}_{2} \mathrm{O}\right) \delta 3.56,2.99$; HRMS $m / z\left(\mathrm{ES}^{-}\right)$[found $\mathrm{M}^{-} 374.9855, \mathrm{C}_{7} \mathrm{H}_{14} \mathrm{O}_{12} \mathrm{NaP}_{2}$ requires $\mathrm{M}^{-}$, 374.9858], $\mathrm{m} / \mathrm{z}, 375\left(\left[\mathrm{C}_{7} \mathrm{H}_{14} \mathrm{NaO}_{12} \mathrm{P}_{2}\right], 70\right), 352\left(\left[\mathrm{C}_{7} \mathrm{H}_{15} \mathrm{O}_{12} \mathrm{P}_{2}\right]^{-}\right.$, $100), 273\left(\left[\mathrm{C}_{7} \mathrm{H}_{14} \mathrm{O}_{9} \mathrm{P}\right], 10\right)$.

$(+)$-1D-1,5-Bis- $O$-allyl-2,3,6-tris- $O$-benzyl-4- $O$-(4-methoxybenzyl)-myo-inositol (17). 11 (2.3 g, $4.3 \mathrm{mmol})$ was dissolved in dry $\mathrm{N}, \mathrm{N}$-dimethylformamide $(80 \mathrm{~mL})$ under an atmosphere of nitrogen, the solution was cooled to $0{ }^{\circ} \mathrm{C}$, and sodium hydride $(191 \mathrm{mg}, 60 \%$ dispersion in mineral oil, $4.8 \mathrm{mmol}$ ) was added. The resulting mixture was allowed to warm to rt and stirred for $1 \mathrm{~h}$, then it was recooled to $0{ }^{\circ} \mathrm{C}$, and tetra- $n$-butylammonium iodide $(80 \mathrm{mg}, 216$ $\mu \mathrm{mol}$ ) and 4-methoxybenzyl chloride (747 mg, $647 \mu \mathrm{L}, 4.8 \mathrm{mmol}$ ) were added. The mixture was allowed to warm to $\mathrm{rt}$ and stirred overnight. The sodium hydride was quenched with water $(3 \mathrm{~mL})$, the solvent removed under reduced pressure, and the residue reconstituted in ethyl acetate $(20 \mathrm{~mL})$ and water $(20 \mathrm{~mL})$. The layers were separated, and the aqueous layer was extracted with ethyl acetate $(3 \times 10 \mathrm{~mL})$. The combined organic layers were washed with brine $(20 \mathrm{~mL})$, dried (magnesium sulfate), filtered, and concentrated under reduced pressure to give a pale yellow oil. Purification by silica gel column chromatography, eluting with ethyl acetate and petroleum ether (10:90), yielded $17(2.7 \mathrm{~g}, 95 \%)$ as a colorless solid: $R_{f} 0.6$ (ethyl acetate/petroleum ether, 30:70); $[\alpha]_{\mathrm{D}}^{25}+6.4\left(c 0.6\right.$ in $\left.\mathrm{CHCl}_{3}\right) ; \mathrm{mp} 58-59{ }^{\circ} \mathrm{C}$ (from ethyl acetate/ petroleum ether); $v_{\max }\left(\mathrm{KBr}\right.$ disk)/ $\mathrm{cm}^{-1} 3058.8(\mathrm{w}), 3031.8(\mathrm{w})$, 2921.3 (m), $1725.6(\mathrm{w}), 1613.9(\mathrm{~m}), 1514.1$ (s), 1454.3 (m), 1359.1 (m), $1302.1(\mathrm{w}), 1250.3(\mathrm{~s}), 1172.6(\mathrm{w}), 1074.4(\mathrm{~s}), 1035.6(\mathrm{~s})$, $917.3(\mathrm{~m}), 821.8(\mathrm{~m}), 744.7(\mathrm{~s}), 697.4(\mathrm{~s}), 605.7(\mathrm{w}) ;{ }^{1} \mathrm{H}$ NMR $\left(300 \mathrm{MHz}, \mathrm{CDCl}_{3}\right) \delta 7.37-7.16(\mathrm{~m}, 17 \mathrm{H}), 6.76(\mathrm{~d}, J=8.7 \mathrm{~Hz}$, $2 \mathrm{H}), 5.99-5.77(\mathrm{~m}, 2 \mathrm{H}), 5.26-5.19(\mathrm{~m}, 2 \mathrm{H}), 5.12-5.07(\mathrm{~m}, 2 \mathrm{H})$, $4.81-4.77(\mathrm{~m}, 3 \mathrm{H}), 4.73(\mathrm{~d}, J=10.2 \mathrm{~Hz}, 1 \mathrm{H}), 4.71(\mathrm{~d}, J=10.5$ $\mathrm{Hz}, 1 \mathrm{H}), 4.67(\mathrm{~d}, J=10.2 \mathrm{~Hz}, 1 \mathrm{H}), 4.61(\mathrm{~d}, J=11.8 \mathrm{~Hz}, 1 \mathrm{H})$, $4.53(\mathrm{~d}, J=11.8 \mathrm{~Hz}, 1 \mathrm{H}), 4.28(\mathrm{dt}, J=5.6,1.5 \mathrm{~Hz}, 2 \mathrm{H}), 4.03-$ $3.99(\mathrm{~m}, 2 \mathrm{H}) 3.96-3.86(\mathrm{~m}, 3 \mathrm{H}), 3.72(\mathrm{~s}, 3 \mathrm{H}), 3.24-3.18(\mathrm{~m}, 2 \mathrm{H})$, $3.12(\mathrm{dd}, J=10.0,2.3 \mathrm{~Hz}, 1 \mathrm{H}) ;{ }^{13} \mathrm{C} \mathrm{NMR}\left(75 \mathrm{MHz}, \mathrm{CDCl}_{3}\right) \delta$ $159.6,139.5,139.4,139.0,135.9,135.4,131.5,130.3,128.83$, $128.8,128.7,128.6,128.3,128.03,128.0,127.8,117.1,117.0$, 114.2, 83.8, 82.1, 81.8, 81.3, 81.0, 76.4, 76.1, 75.1, 74.8, 74.5, 73.3, 72.1, 55.7; HRMS $\mathrm{m} / \mathrm{z}\left(\mathrm{ES}^{+}\right)$[found $(\mathrm{M}+\mathrm{Na})^{+} 673.3165$, $\mathrm{C}_{41} \mathrm{H}_{46} \mathrm{O}_{7} \mathrm{Na}$ requires $\left.\mathrm{M}^{+}, 673.3141\right], \mathrm{m} / z\left(\mathrm{ES}^{+}\right) 673\left([\mathrm{M}+\mathrm{Na}]^{+}\right.$, 100). Anal. Calcd for $\mathrm{C}_{41} \mathrm{H}_{46} \mathrm{O}_{7}$ : C, 75.7; H, 7.1. Found: C, 75.7; H, 7.4.

$(-)-1 \mathrm{D}-2,3,6$-Tris- $O$-benzyl-4- $O$-(4-methoxybenzyl)-myo-inositol (18). Wilkinson's catalyst ( $22 \mathrm{mg}, 24 \mu \mathrm{mol}$ ) was dissolved in dry tetrahydrofuran $(0.5 \mathrm{~mL})$ under an atmosphere of nitrogen, $n$-butyllithium (1.6 M solution in hexanes, $23 \mu \mathrm{L}, 36 \mu \mathrm{mol})$ was added, and the resulting mixture was stirred for $10 \mathrm{~min}$ at $\mathrm{rt}$. The mixture was then cannulated onto a solution of $\mathbf{1 7}(40 \mathrm{mg}, 61 \mu \mathrm{mol})$ in dry tetrahydrofuran $(0.5 \mathrm{~mL})$ under an atmosphere of nitrogen and the resulting mixture heated under reflux for $6 \mathrm{~h}$. The mixture was cooled to $\mathrm{rt}$ and the solvent removed under reduced pressure to give a dark red residue. ${ }^{1} \mathrm{H}$ NMR analysis indicated that the allyl groups had completely isomerized. The residue was suspended in ethanol, the resulting mixture filtered through Celite, and the solvent removed under reduced pressure. The resulting residue was dissolved in a solution of methanol and dichloromethane $(2: 3,1$ $\mathrm{mL}$ ) under an atmosphere of nitrogen, acetyl chloride $(3 \mathrm{mg}, 3 \mu \mathrm{L}$, $37 \mu \mathrm{mol}$ ) was added, and the resulting mixture was stirred for $3 \mathrm{~h}$. The generated hydrochloric acid was quenched with triethylamine $(50 \mu \mathrm{L})$, the solvent removed under reduced pressure, and the residue adsorbed onto silica gel and purified by column chromatography, eluting with ethyl acetate and petroleum ether (20:80), to yield 18 (31 mg, 89\%) as a colorless gum: $R_{f} 0.54$ (ethyl acetate/ petroleum ether, 50:50); $[\alpha]_{\mathrm{D}}^{25}-6.7\left(c 0.56\right.$ in $\left.\mathrm{CHCl}_{3}\right) ; v_{\max }$ (thin film) $/ \mathrm{cm}^{-1} 3555.0(\mathrm{~m}), 3449.2(\mathrm{~m}), 3055.3(\mathrm{~m}), 2924.8(\mathrm{~s}), 1612.8$ (m), $1586.1(\mathrm{w}), 1514.1(\mathrm{~s}), 1455.0(\mathrm{~s}), 1364.3(\mathrm{~m}), 1265.7(\mathrm{~s})$, $1250.2(\mathrm{~m}), 1113.2(\mathrm{~m}), 1069.2(\mathrm{~s}), 1028.0(\mathrm{~m}), 933.9(\mathrm{w}), 822.7$ (w), 737.3 (s), 701.9 (s); ${ }^{1} \mathrm{H}$ NMR (300 MHz, $\left.\mathrm{CDCl}_{3}\right) \delta$ 7.29$7.18(\mathrm{~m}, 17 \mathrm{H}), 6.79(\mathrm{~d}, J=8.7 \mathrm{~Hz}, 2 \mathrm{H}), 4.92(\mathrm{~d}, J=11.5 \mathrm{~Hz}$, $1 \mathrm{H}), 4.84(\mathrm{~d}, J=11.0 \mathrm{~Hz}, 1 \mathrm{H}), 4.83(\mathrm{~d}, J=11.4 \mathrm{~Hz}, 1 \mathrm{H}), 4.73-$ $4.65(\mathrm{~m}, 2 \mathrm{H}), 4.62(\mathrm{~s}, 2 \mathrm{H}), 4.61(\mathrm{~d}, J=11.0 \mathrm{~Hz}, 1 \mathrm{H}), 3.98(\mathrm{t}, J=$ $2.6 \mathrm{~Hz}, 1 \mathrm{H}), 3.81(J=9.2 \mathrm{~Hz}, 1 \mathrm{H}), 3.73(\mathrm{~s}, 3 \mathrm{H}), 3.61(\mathrm{~d}, J=9.5$ $\mathrm{Hz}, 1 \mathrm{H}), 3.46-3.34(\mathrm{~m}, 3 \mathrm{H}), 2.39(\mathrm{~d}, J=2.0 \mathrm{~Hz}, 1 \mathrm{H}), 2.22(\mathrm{~d}, J$ $=6.4 \mathrm{~Hz}, 1 \mathrm{H}) ;{ }^{13} \mathrm{C} \mathrm{NMR}\left(75 \mathrm{MHz}, \mathrm{CDCl}_{3}\right) \delta 159.7,139.2,139.1$, 138.6, 131.2, 130.2, 129.0, 128.9, 128.8, 128.5, 128.2, 128.2, 128.1, 128.0, 114.4, 82.1, 81.4, 81.3, 77.9, 77.5, 77.1, 75.4, 73.1, 72.6, 55.7; HRMS $m / z\left(\mathrm{ES}^{+}\right)$[found $(\mathrm{M}+\mathrm{Na})^{+} 593.2504, \mathrm{C}_{35} \mathrm{H}_{38} \mathrm{O}_{7} \mathrm{Na}$ requires $\left.\mathrm{M}^{+}, 593.2515\right], \mathrm{m} / z\left(\mathrm{ES}^{+}\right) 593\left([\mathrm{M}+\mathrm{Na}]^{+}, 100\right)$. Anal. Calcd for $\mathrm{C}_{35} \mathrm{H}_{38} \mathrm{O}_{7}$ : C, 73.66; H, 6.7. Found: C, 73.25; H, 6.75.

(+)-1D-2,3,6-Tris- $O$-benzyl-4- $O$-(4-methoxybenzyl)-myo-inositol 1,5-Bis(dibenzyl phosphate) (19). Bis(benzyloxy) $(N, N$-diisopropylamino)phosphine $(3.0 \mathrm{~g}, 8.8 \mathrm{mmol})$ was stirred with $1 H^{-}$ tetrazole $(613 \mathrm{mg}, 8.8 \mathrm{mmol})$ for $10 \mathrm{~min}$ under an atmosphere of nitrogen at rt. $18(1.0 \mathrm{~g}, 1.8 \mathrm{mmol})$ dissolved in dry dichloromethane $(20 \mathrm{~mL})$ was added by cannula and the resulting mixture stirred overnight. The mixture was cooled to $-78{ }^{\circ} \mathrm{C}$, and 3-chloroperoxybenzoic acid $(1.5 \mathrm{~g}, 8.8 \mathrm{mmol})$ was added. The resulting mixture was allowed to warm to rt and stirred for $30 \mathrm{~min}$. The 3-chloroperoxybenzoic acid was quenched with a $10 \%$ aqueous solution of sodium hydrogen sulfite $(20 \mathrm{~mL})$. The layers were separated, and the aqueous layer was extracted with dichloromethane $(3 \times 10 \mathrm{~mL})$. The combined organic layers were washed with a saturated aqueous solution of sodium hydrogen carbonate $(10 \mathrm{~mL})$ and brine $(10 \mathrm{~mL})$, dried (magnesium sulfate), filtered, and concentrated under reduced pressure. Purification by silica gel column chromatography, eluting with ethyl acetate and petroleum ether (30:70, then 50:50), yielded $19(1.4 \mathrm{~g}, 75 \%)$ as a colorless gum: $R_{f} 0.39$ (ethyl acetate/petroleum, $50: 50) ;[\alpha]_{\mathrm{D}}^{25}+7.5\left(c 0.3\right.$ in $\left.\mathrm{CHCl}_{3}\right) ; v_{\max }($ thin film $) / \mathrm{cm}^{-1} 3064.2$ (m), $3033.0(\mathrm{~m}), 2934.8(\mathrm{~m}), 1612.8(\mathrm{~m}), 1586.4(\mathrm{w}), 1514.3(\mathrm{~s})$, $1497.6(\mathrm{~m}), 1455.6(\mathrm{~s}), 1364.6(\mathrm{~m}), 1250.1(\mathrm{~s}), 1214.6(\mathrm{~m}), 1073.8$ (w), 1012.2 (s), 880.7 (m), $823.0(\mathrm{w}), 737.3$ (s), 696.6 (s); ${ }^{1} \mathrm{H}$ NMR $\left(300 \mathrm{MHz}, \mathrm{CDCl}_{3}\right) \delta 7.30-6.93(\mathrm{~m}, 37 \mathrm{H}), 6.67(\mathrm{~d}, J=8.7 \mathrm{~Hz}$, $2 \mathrm{H}), 4.87-4.62(\mathrm{~m}, 14 \mathrm{H}), 4.48(\mathrm{~d}, J=11.5 \mathrm{~Hz}, 1 \mathrm{H}), 4.43(\mathrm{~d}, J=$ $11.5 \mathrm{~Hz}, 1 \mathrm{H}), 4.34(\mathrm{dd}, J=18.2,9.0 \mathrm{~Hz}, 1 \mathrm{H}), 4.26(\mathrm{t}, J=2.3 \mathrm{~Hz}$, $1 \mathrm{H}), 4.18-4.12(\mathrm{~m}, 1 \mathrm{H}), 4.03-3.93(\mathrm{~m}, 2 \mathrm{H}), 3.67(\mathrm{~s}, 3 \mathrm{H}), 3.31$ (dd, $J=9.7,2.3 \mathrm{~Hz}, 1 \mathrm{H}) ;{ }^{13} \mathrm{C} \mathrm{NMR}\left(75 \mathrm{MHz}, \mathrm{CDCl}_{3}\right) \delta 159.3$, 139.0, 138.6, 138.2, $136.5(\mathrm{~d}, J=4.8 \mathrm{~Hz}), 136.4(\mathrm{~d}, J=4.8 \mathrm{~Hz})$, $136.1(\mathrm{~d}, J=2.3 \mathrm{~Hz}), 136.0(\mathrm{~d}, J=1.8 \mathrm{~Hz}), 131.0,129.8,129.0$, $128.9,128.8,128.8,128.7,128.5,128.2,128.1,128.1,128.0,127.9$, $127.7,113.9,80.9(\mathrm{dd}, J=7.0,1.5 \mathrm{~Hz}), 80.4,79.1(\mathrm{~d}, J=2.8$ $\mathrm{Hz}), 78.8(\mathrm{dd}, J=7.5,3.3 \mathrm{~Hz}), 78.5(\mathrm{~d}, J=5.9 \mathrm{~Hz}), 76.3,75.5$, 75.1, 75.0, 73.1, $69.9(\mathrm{~d}, J=5.7 \mathrm{~Hz}), 69.7(\mathrm{~d}, J=5.5 \mathrm{~Hz}), 69.6$ $(\mathrm{d}, J=4.9 \mathrm{~Hz}), 55.6 ;{ }^{31} \mathrm{P}$ NMR $\left(121 \mathrm{MHz}, \mathrm{CDCl}_{3}\right) \delta-0.22,-0.61$; HRMS $m / z\left(\mathrm{ES}^{+}\right)$[found $(\mathrm{M}+\mathrm{Na})^{+} 1113.3711, \mathrm{C}_{63} \mathrm{H}_{64} \mathrm{O}_{13} \mathrm{NaP}_{2}$ 
requires $\left.\mathrm{M}^{+}, 1113.3720\right], \mathrm{m} / z\left(\mathrm{ES}^{+}\right) 1113\left([\mathrm{M}+\mathrm{Na}]^{+}, 100\right)$. Anal. Calcd for $\mathrm{C}_{63} \mathrm{H}_{64} \mathrm{O}_{13} \mathrm{P}_{2}$ : C, 69.35; H, 5.9. Found: C, 69.7; H, 5.8.

(+)-1D-2,3,6-Tris- $O$-benzyl-myo-inositol 1,5-Bis(dibenzyl phosphate) (20). 19 (327 mg, $0.3 \mathrm{mmol})$ was dissolved in acetonitrile and water $(4: 1,5 \mathrm{~mL})$, and ceric ammonium nitrate $(987 \mathrm{mg}, 1.8$ mmol) was added at $\mathrm{rt}$. The resulting orange solution was stirred for $2 \mathrm{~h}$. The solvent was removed under reduced pressure, the residue was reconstituted in ethyl acetate $(5 \mathrm{~mL})$ and water $(5 \mathrm{~mL})$, the layers were separated, and the aqueous layer was extracted with ethyl acetate $(3 \times 5 \mathrm{~mL})$. The combined organic layers were washed with a saturated aqueous solution of sodium hydrogen carbonate $(10 \mathrm{~mL})$, dried (magnesium sulfate), filtered, and concentrated under reduced pressure to give an orange residue. Silica gel column chromatography, eluting with ethyl acetate and petroleum ether (50: 50), followed by crystallization from diethyl ether/dichloromethane/ petroleum ether, yielded $\mathbf{2 0}(232 \mathrm{mg}, 73 \%)$ as a colorless solid: $R_{f}$ 0.24 (ethyl acetate/petroleum, 50:50); $[\alpha]_{\mathrm{D}}^{25}+1.6(c \quad 0.6$ in $\mathrm{CHCl}_{3}$ ); $\mathrm{mp} 125-126{ }^{\circ} \mathrm{C} ; v_{\max }$ (thin film) $/ \mathrm{cm}^{-1} 3397.3$ (s), 3064.6 (m), $3030.5(\mathrm{~m}), 2938.6(\mathrm{~m}), 2890.7(\mathrm{~m}), 1497.5(\mathrm{~m}), 1455.5(\mathrm{~s})$, $1367.4(\mathrm{~m}), 1269.4(\mathrm{~s}), 1240.1(\mathrm{~s}), 1216.2(\mathrm{~m}), 1162.8(\mathrm{~m}), 1129.1$ (m), 1068.7 (s), $1013.4(\mathrm{~s}), 888.8(\mathrm{~m}), 737.0$ (s), $695.3(\mathrm{~s}), 589.3$ (w), $554.7(\mathrm{w}), 502.2(\mathrm{~m}) ;{ }^{1} \mathrm{H}$ NMR $\left(300 \mathrm{MHz}, \mathrm{CDCl}_{3}\right) \delta 7.37-$ $7.12(\mathrm{~m}, 35 \mathrm{H}), 5.05-4.70(\mathrm{~m}, 12 \mathrm{H}), 4.62(\mathrm{~d}, J=11.8 \mathrm{~Hz}, 1 \mathrm{H})$, $4.57(\mathrm{~d}, J=11.8 \mathrm{~Hz}, 1 \mathrm{H}), 4.30(\mathrm{t}, J=2.3 \mathrm{~Hz}, 1 \mathrm{H}), 4.25-4.17$ $(\mathrm{m}, 3 \mathrm{H}), 4.08-3.98(\mathrm{~m}, 1 \mathrm{H}), 3.87$ (br s, $1 \mathrm{H}), 3.25(\mathrm{dd}, J=9.2$, $2.0 \mathrm{~Hz}, 1 \mathrm{H}) ;{ }^{13} \mathrm{C} \mathrm{NMR}\left(75 \mathrm{MHz}, \mathrm{CDCl}_{3}\right) \delta 138.6,138.0,137.8$, $135.8-135.6$ (m) $128.6,128.52,128.5,128.46,128.4,128.25$, $128.2,127.8,127.7,127.6,127.4,82.4(\mathrm{dd}, J=6.1,1.9 \mathrm{~Hz}), 79.1$, 78.3-78.0 (m), 76.0, 75.2, 75.1, 72.9, 72.0, $69.6(\mathrm{~d}, J=5.2 \mathrm{~Hz})$, $69.5(\mathrm{~d}, J=5.8 \mathrm{~Hz}), 69.3(\mathrm{~d}, J=5.5 \mathrm{~Hz}) ;{ }^{31} \mathrm{P}$ NMR $(121 \mathrm{MHz}$, $\left.\mathrm{CDCl}_{3}\right): \delta$ 1.34, -0.49 ; HRMS m/z $\left(\mathrm{ES}^{+}\right)$[found $(\mathrm{M}+\mathrm{Na})^{+}$ 993.3147, $\mathrm{C}_{55} \mathrm{H}_{56} \mathrm{O}_{12} \mathrm{NaP}_{2}$ requires $\mathrm{M}^{+}$, 993.3145], $\mathrm{m} / \mathrm{z}\left(\mathrm{ES}^{+}\right) 993$ $\left([\mathrm{M}+\mathrm{Na}]^{+}, 100\right)$. Anal. Calcd for $\mathrm{C}_{55} \mathrm{H}_{56} \mathrm{O}_{12} \mathrm{P}_{2}: \mathrm{C}, 68.0 ; \mathrm{H}, 5.8$. Found: $\mathrm{C}, 68.1 ; \mathrm{H}, 5.65$.

$(+)-1 \mathrm{D}-2,3,6$-Tris- $O$-benzyl-4- $O$-(dimethylphosphinyl)-myoinositol 1,5-Bis(dibenzyl phosphate) (21). 20 (40 mg, $41 \mu \mathrm{mol}$ ) was dissolved in dry $N, N$-dimethylformamide $(1 \mathrm{~mL})$ under an atmosphere of nitrogen. 2,6-Lutidine ( $22 \mathrm{mg}, 24 \mu \mathrm{L}, 206 \mu \mathrm{mol}$ ) was added, and the resulting mixture was cooled to $-42{ }^{\circ} \mathrm{C}$. Dimethylphosphinic chloride $(19 \mathrm{mg}, 165 \mu \mathrm{mol})$ dissolved in dry $N, N$-dimethylformamide $(0.5 \mathrm{~mL})$ was added by cannula. The resulting mixture was allowed to warm to $\mathrm{rt}$ and stirred for $22 \mathrm{~h}$. The solvent was removed under reduced pressure and the residue adsorbed onto silica gel and purified by silica gel column chromatography, eluting with methanol and ethyl acetate (1:99) (three times), to give $\mathbf{2 1}$ (33 mg, 76\%) as a colorless solid. Further purification was achieved by crystallization from ethyl acetate and petroleum ether: $R_{f} 0.52$ (methanol/ethyl acetate, $5: 95$ ); $[\alpha]_{\mathrm{D}}^{22}$ +6.2 (c 0.85 in $\mathrm{CHCl}_{3}$ ); $\mathrm{mp} 105-106{ }^{\circ} \mathrm{C}$ (from ethyl acetate/ petroleum ether); $v_{\max }\left(\mathrm{KBr}\right.$ disk) $/ \mathrm{cm}^{-1} 3058.8(\mathrm{~m}), 3033.4(\mathrm{~m})$, 2924.4 (m), 2879.5 (m), $1498.2(\mathrm{~m}), 1455.4(\mathrm{~m}), 1381.0(\mathrm{w}), 1262.8$ (s), $1215.8(\mathrm{~s}), 1124.5(\mathrm{w}), 1017.2(\mathrm{~s}), 939.9(\mathrm{w}), 872.2(\mathrm{~m}), 736.4$ (s), 695.9 (s), 594.5 (w), 507.5 (w); ${ }^{1} \mathrm{H}$ NMR (300 MHz, $\mathrm{CDCl}_{3}$ ) $\delta 7.32-6.95(\mathrm{~m}, 35 \mathrm{H}), 5.05(\mathrm{dd}, J=11.8,6.1 \mathrm{~Hz}, 1 \mathrm{H}), 4.92-$ $4.59(\mathrm{~m}, 12 \mathrm{H}), 4.44(\mathrm{~d}, J=11.3 \mathrm{~Hz}, 1 \mathrm{H}), 4.38-4.32(\mathrm{~m}, 2 \mathrm{H})$, $4.28(\mathrm{t}, J=2.6 \mathrm{~Hz}, 1 \mathrm{H}), 4.21-4.15(\mathrm{~m}, 1 \mathrm{H}), 4.01(\mathrm{t}, J=9.5 \mathrm{~Hz}$, $1 \mathrm{H}), 3.29(\mathrm{dd}, J=10.0,2.0 \mathrm{~Hz}, 1 \mathrm{H}), 1.40(\mathrm{~d}, J=14.0 \mathrm{~Hz}, 3 \mathrm{H})$, $1.26(\mathrm{~d}, J=14.0 \mathrm{~Hz}, 3 \mathrm{H}) ;{ }^{13} \mathrm{C} \mathrm{NMR}\left(75 \mathrm{MHz}, \mathrm{CDCl}_{3}\right) \delta 138.24$, $138.2,136.9,136.0(\mathrm{~d}, J=7.1 \mathrm{~Hz}), 135.9(\mathrm{~d}, J=5.8 \mathrm{~Hz}) 135.6-$ $135.5(\mathrm{~m}), 128.6,128.5,128.5,128.4,128.3,128.2,128.1,128.06$, $127.9,127.8,127.7,127.6,127.4,127.2,79.4-79.3(\mathrm{~m}), 78.1-$ $77.9(\mathrm{~m}), 75.3,74.9,74.8,73.3-73.2(\mathrm{~m}), 72.2,69.6(\mathrm{~d}, J=6.2$ $\mathrm{Hz}), 69.5(\mathrm{~d}, J=5.5 \mathrm{~Hz}), 69.3(\mathrm{~d}, J=4.9 \mathrm{~Hz}), 17.6(\mathrm{~d}, J=69.7$ $\mathrm{Hz}), 16.3$ (d, $J=73.5 \mathrm{~Hz}) ;{ }^{31} \mathrm{P}$ NMR $\left(121 \mathrm{MHz}, \mathrm{CDCl}_{3}\right) \delta 57.3$, $-0.17,-0.54$; HRMS $m / z\left(\mathrm{ES}^{+}\right)$[found $(\mathrm{M}+\mathrm{Na})^{+}$1069.3218, $\mathrm{C}_{57} \mathrm{H}_{61} \mathrm{O}_{13} \mathrm{NaP}_{3}$ requires $\left.\mathrm{M}^{+}, 1069.3223\right], \mathrm{m} / z\left(\mathrm{ES}^{+}\right) 1069([\mathrm{M}+$ $\left.\mathrm{Na}]^{+}, 100\right)$. Anal. Calcd for $\mathrm{C}_{57} \mathrm{H}_{61} \mathrm{O}_{13} \mathrm{P}_{3}$ : C, 65.4; H, 5.9. Found: C, 65.05; H, 5.6.
(+)-1D-4-O-(Dimethylphosphinyl)-myo-inositol 1,5-Bisphosphate (Sodium Salt) (3). 21 (71 mg, $68 \mu \mathrm{mol})$ was dissolved in tert-butyl alcohol and water $(6: 1,12 \mathrm{~mL})$, sodium hydrogen carbonate $(23 \mathrm{mg}, 271 \mu \mathrm{mol})$ and palladium black (145 mg, 1.4 $\mathrm{mmol}$ ) were added, and the flask was flushed three times with a balloon of hydrogen and then stirred for $7 \mathrm{~h}$ at $\mathrm{rt}$ under an atmosphere of hydrogen. The organic layer was removed by filtration, the dark residue washed with water $(4 \times 3 \mathrm{~mL})$, and the collected aqueous layer lyophilized to yield $\mathbf{3}$ as a colorless solid (32 mg, 93\%); $[\alpha]_{\mathrm{D}}^{22}+0.81\left(c 0.6\right.$ in $\left.\mathrm{H}_{2} \mathrm{O}\right) ; v_{\max }(\mathrm{KBr}$ disk $) / \mathrm{cm}^{-1}$ 3423.3 (s), $2198.8(\mathrm{~m}), 1655.3(\mathrm{w}), 1309.1(\mathrm{w}), 1188.8(\mathrm{~s}), 1116.1$ (s), $1053.1(\mathrm{~s}), 950.1(\mathrm{~s}), 920.3(\mathrm{~m}), 883.9(\mathrm{~m}), 811.2(\mathrm{w}), 721.7$ (w), $513.8(\mathrm{~m}) ;{ }^{1} \mathrm{H}$ NMR $\left(300 \mathrm{MHz}, \mathrm{D}_{2} \mathrm{O}\right) \delta 4.29-4.15(\mathrm{~m}, 2 \mathrm{H})$, $3.97-3.77(\mathrm{~m}, 3 \mathrm{H}), 3.63(\mathrm{dd}, J=9.7,2.8 \mathrm{~Hz}, 1 \mathrm{H}), 1.58(\mathrm{~d}, J=$ $11.0 \mathrm{~Hz}, 3 \mathrm{H}), 1.53(\mathrm{~d}, J=11.0 \mathrm{~Hz}, 3 \mathrm{H}) ;{ }^{13} \mathrm{C} \mathrm{NMR}(75 \mathrm{MHz}$, $\left.\mathrm{D}_{2} \mathrm{O}\right) \delta 76.8(\mathrm{dd}, J=7.7,6.3 \mathrm{~Hz}), 76.1-75.9(\mathrm{~m}), 74.4(\mathrm{~d}, J=$ $5.5 \mathrm{~Hz}), 72.2(\mathrm{~d}, J=7.2 \mathrm{~Hz}), 70.8,69.2,15.3(\mathrm{~d}, J=95.0 \mathrm{~Hz})$, $15.1(\mathrm{~d}, J=95.0 \mathrm{~Hz}) ;{ }^{31} \mathrm{P}$ NMR $\left(121 \mathrm{MHz}, \mathrm{D}_{2} \mathrm{O}\right) \delta 67.1,1.63$, 1.41; HRMS $\mathrm{m} / \mathrm{z}$ (MALDI, matrix 3AQ, internal calculation on glucose sulfate and ATP) [found $\left(\mathrm{C}_{8} \mathrm{H}_{18} \mathrm{O}_{13} \mathrm{P}_{3}\right)^{-} 414.9939, \mathrm{C}_{8} \mathrm{H}_{18} \mathrm{O}_{13} \mathrm{P}_{3}$ requires $\left.\mathrm{M}^{-}, 414.9960\right], \mathrm{m} / \mathrm{z}$ (MALDI, matrix 3AQ, external calculation on glucose sulfate and ATP $) 415\left[\left(\mathrm{C}_{8} \mathrm{H}_{18} \mathrm{O}_{13} \mathrm{P}_{3}\right)^{-}\right]$.

(+)-1D-2,3,6-Tris- $O$-benzyl-4- $O$-(di- $\boldsymbol{n}$-butylphosphinyl)-myoinositol 1,5-Bis(dibenzyl phosphate) (22). 20 (100 mg, $103 \mu \mathrm{mol})$ was dissolved in dry $N, N$-dimethylformamide $(4 \mathrm{~mL})$ under an atmosphere of nitrogen and the mixture cooled to $-42{ }^{\circ} \mathrm{C}$. 4-(Dimethylamino)pyridine (catalytic amount) was added, followed by dry triethylamine $(52 \mathrm{mg}, 72 \mu \mathrm{L}, 515 \mu \mathrm{mol})$ and di- $n$ butylphosphinyl chloride ( $82 \mathrm{mg}, 79 \mu \mathrm{L}, 416 \mu \mathrm{mol}$ ). The mixture was allowed to warm to $\mathrm{rt}$ and stirred overnight. The di- $n$ butylphosphinic chloride was quenched with water $(0.5 \mathrm{~mL})$, the solvent was removed under reduced pressure, and the residue was reconstituted in ethyl acetate $(2 \mathrm{~mL})$ and water $(2 \mathrm{~mL})$. The layers were separated, and the aqueous layer was extracted with ethyl acetate $(3 \times 5 \mathrm{~mL})$. The combined organic layers were dried (magnesium sulfate), filtered, and concentrated under reduced pressure. Purification by silica gel column chromatography, eluting with ethyl acetate and petroleum ether (60:40), gave 22 as a colorless solid which was crystallized from ethyl acetate and petroleum ether $(76 \mathrm{mg}, 65 \%): R_{f} 0.25$ (ethyl acetate/petroleum ether, 60:40); $[\alpha]_{\mathrm{D}}^{25}+0.5$ (c 0.27 in $\mathrm{CHCl}_{3}$ ); mp $104-105{ }^{\circ} \mathrm{C}$ (from ethyl acetate/petroleum ether); $v_{\max }(\mathrm{KBr} \mathrm{disc}) / \mathrm{cm}^{-1} 3064.4$ (m), 3030.8 (m), $2930.0(\mathrm{~m}), 1457.3(\mathrm{w}), 1381.8(\mathrm{w}), 1261.3(\mathrm{~m})$, $1211.2(\mathrm{w}), 1160.8(\mathrm{w}), 1127.3(\mathrm{w}), 1037.8(\mathrm{~s}), 1015.5(\mathrm{~s}), 881.1$ (w), 867.1 (w), $135.7(\mathrm{~m}), 695.9(\mathrm{~s}), 593.0(\mathrm{w}) ;{ }^{1} \mathrm{H}$ NMR (300 $\left.\mathrm{MHz}, \mathrm{CDCl}_{3}\right) \delta 7.28-6.91(\mathrm{~m}, 35 \mathrm{H}), 5.11(\mathrm{dd}, J=11.8,6.1 \mathrm{~Hz}$, $1 \mathrm{H}), 4.92-4.57(\mathrm{~m}, 12 \mathrm{H}), 4.45(\mathrm{~d}, J=11.5 \mathrm{~Hz}, 1 \mathrm{H}), 4.35-4.30$ $(\mathrm{m}, 3 \mathrm{H}), 4.23-4.16(\mathrm{~m}, 1 \mathrm{H}), 4.02(\mathrm{t}, J=9.5 \mathrm{~Hz}, 1 \mathrm{H}), 3.30(\mathrm{dd}, J$ $=9.7,1.8 \mathrm{~Hz}, 1 \mathrm{H}), 1.73-0.91(\mathrm{~m}, 12 \mathrm{H}) 0.71(\mathrm{t}, J=7.2 \mathrm{~Hz}, 3 \mathrm{H})$, $0.65(\mathrm{t}, J=7.2 \mathrm{~Hz}, 3 \mathrm{H}) ;{ }^{13} \mathrm{C}$ NMR $\left(75 \mathrm{MHz}, \mathrm{CDCl}_{3}\right) \delta 138.3$, $138.2,137.8,136.2(\mathrm{~d}, J=8.1 \mathrm{~Hz}), 135.9(\mathrm{~d}, J=6.6 \mathrm{~Hz}), 135.6$ $(\mathrm{d}, J=7.5 \mathrm{~Hz}), 135.5(\mathrm{~d}, J=6.9 \mathrm{~Hz}), 128.6,128.5,128.4,128.31$, $128.3,128.13,128.1,127.84,127.8,127.7,127.64,127.6,127.3$, 127.2, $79.6(\mathrm{~d}, J=6.1 \mathrm{~Hz}), 78.2-77.9(\mathrm{~m}), 75.3,74.72,74.7,73.2$, $72.0,69.5(\mathrm{~d}, J=4.2 \mathrm{~Hz}), 69.3(\mathrm{~d}, J=6.7 \mathrm{~Hz}), 69.2(\mathrm{~d}, J=5.4$ $\mathrm{Hz}), 28.7$ (d, $J=30.9 \mathrm{~Hz}), 27.5$ (d, $J=33.3 \mathrm{~Hz}), 24.5$ (d, $J=2.5$ $\mathrm{Hz}), 24.4(\mathrm{~d}, J=3.6 \mathrm{~Hz}), 24.1-23.8(\mathrm{~m}), 13.7,13.6 ;{ }^{31} \mathrm{P}$ NMR $\left(121 \mathrm{MHz}, \mathrm{CDCl}_{3}\right) \delta 62.1,-0.37,-0.60 ; \mathrm{HRMS} \mathrm{m} / \mathrm{z}\left(\mathrm{ES}^{+}\right)$[found $\left[\mathrm{C}_{63} \mathrm{H}_{73} \mathrm{O}_{13} \mathrm{NaP}_{3}\right]^{+} 1153.4181, \mathrm{C}_{63} \mathrm{H}_{73} \mathrm{O}_{13} \mathrm{NaP}_{3}$ requires $\mathrm{M}^{+}$, 1153.4162], $\mathrm{m} / z\left(\mathrm{ES}^{+}\right) 1153\left([\mathrm{M}+\mathrm{Na}]^{+}, 100\right)$.

(-)-1D-4-O-(Di-n-butylphosphinyl)-myo-inositol 1,5-Bisphosphate (Sodium Salt) (4). 22 (79 mg, $70 \mu \mathrm{mol})$ was dissolved in tert-butyl alcohol and water $(5: 1,12 \mathrm{~mL})$, sodium hydrogen carbonate $(24 \mathrm{mg}, 280 \mu \mathrm{mol})$ and palladium black $(149 \mathrm{mg}, 1.4$ mmol) were added, and the flask was flushed three times with a balloon of hydrogen and then stirred for $8 \mathrm{~h}$ at $\mathrm{rt}$ under an atmosphere of hydrogen. The organic layer was removed by filtration, the dark residue washed with water $(3 \times 5 \mathrm{~mL})$, and the 
collected aqueous layer lyophilized to yield $\mathbf{4}$ as a colorless solid (39 mg, 95\%): $[\alpha]_{\mathrm{D}}^{25}-1.43\left(c 0.5\right.$ in $\left.\mathrm{H}_{2} \mathrm{O}\right) ; v_{\max }(\mathrm{KBr}$ disk $) / \mathrm{cm}^{-1}$ $3428.6(\mathrm{~s}), 2959.6(\mathrm{~s}), 2930.0(\mathrm{~s}), 2868.3(\mathrm{~s}), 1650.3(\mathrm{~m}), 1457.3$, (w), $1376.2(\mathrm{w}), 1236.4(\mathrm{w}), 1114.6(\mathrm{~s}), 972.2(\mathrm{~s}), 900.7(\mathrm{w}), 800.0$ (w), $724.5(\mathrm{w}), 576.2(\mathrm{w}), 537.1(\mathrm{w}) ;{ }^{1} \mathrm{H}$ NMR $\left(300 \mathrm{MHz}, \mathrm{D}_{2} \mathrm{O}\right) \delta$ $4.28-4.25(\mathrm{~m}, 1 \mathrm{H}), 4.20(\mathrm{t}, J=9.2 \mathrm{~Hz}, 1 \mathrm{H}), 3.86-3.72(\mathrm{~m}, 3 \mathrm{H})$, $3.63(\mathrm{dd}, J=9.7,2.8 \mathrm{~Hz}, 1 \mathrm{H}), 1.97-1.77(\mathrm{~m}, 4 \mathrm{H}), 1.51-1.22(\mathrm{~m}$, $8 \mathrm{H}), 0.82-0.76(\mathrm{~m}, 6 \mathrm{H}) ;{ }^{13} \mathrm{C}$ NMR $\left(75 \mathrm{MHz}, \mathrm{D}_{2} \mathrm{O}\right) \delta 76.4(\mathrm{dd}, J$ $=8.3,6.6 \mathrm{~Hz}), 76.2-76.1(\mathrm{~m}), 74.3(\mathrm{~d}, J=5.5 \mathrm{~Hz}), 72.2(\mathrm{~d}, J=$ $7.7 \mathrm{~Hz}), 70.9,69.4,23.6-23.1(\mathrm{~m}), 13.0(\mathrm{~d}, J=1.1 \mathrm{~Hz}), 12.8(\mathrm{~d}$, $J=1.1 \mathrm{~Hz}) ;{ }^{31} \mathrm{P}$ NMR $\left(121 \mathrm{MHz}, \mathrm{D}_{2} \mathrm{O}\right) \delta 70.3,3.9,3.0$; HRMS $\mathrm{m} / \mathrm{z}\left(\mathrm{ES}^{+}\right)$[found $\left[\mathrm{C}_{14} \mathrm{H}_{29} \mathrm{O}_{13} \mathrm{Na}_{3} \mathrm{P}_{3}\right]^{+}$567.0522, $\mathrm{C}_{14} \mathrm{H}_{29} \mathrm{O}_{13} \mathrm{Na}_{3} \mathrm{P}_{3}$ requires $\left.\mathrm{M}^{+}, 567.0514\right], \mathrm{m} / z\left(\mathrm{ES}^{+}\right) 567\left(\left[\mathrm{C}_{14} \mathrm{H}_{29} \mathrm{O}_{13} \mathrm{Na}_{3} \mathrm{P}_{3}\right]^{+}, 100\right)$.

$(+)$-1D-2,3,6-Tris- $O$-benzyl-4- $O$-(methylsulfonyl)-myo-inositol 1,5-Bis(dibenzyl phosphate) (23). 20 (70 mg, $72 \mu \mathrm{mol}$ ) was dissolved in dry dichloromethane $(4 \mathrm{~mL})$ under an atmosphere of nitrogen and the mixture cooled to $-78{ }^{\circ} \mathrm{C}$. 4-(Dimethylamino)pyridine (catalytic amount) was added, followed by dry triethylamine (36 mg, $50 \mu \mathrm{L}, 360 \mu \mathrm{mol}$ ) and methanesulfonyl chloride (33 mg, $22 \mu \mathrm{L}, 288 \mu \mathrm{mol}$ ). The mixture was allowed to warm to rt and stirred for 2 days. The methanesulfonyl chloride was quenched with a saturated aqueous solution of sodium hydrogen carbonate $(2 \mathrm{~mL})$. The layers were separated, and the aqueous layer was extracted with dichloromethane $(3 \times 5 \mathrm{~mL})$. The combined organic layers were dried (magnesium sulfate), filtered, and concentrated under reduced pressure. Purification by silica gel column chromatography, eluting with ethyl acetate and petroleum ether (50:50, then 70:30), gave 23 (42 $\mathrm{mg}, 56 \%$ ) as a colorless gum: $R_{f} 0.25$ (ethyl acetate/petroleum ether, 50:50); $[\alpha]_{\mathrm{D}}^{25}+1.5$ (c 0.94 in $\mathrm{CHCl}_{3}$ ); $v_{\max }$ (thin film) $/ \mathrm{cm}^{-1} 3064.4$ (s), 3033.2 (s), 2931.9 (s), 1956.3 (w), 1884.7 (w), 1813.1 (w), 1726.8 (m), 1606.2 (w), $1497.6(\mathrm{~s}), 1455.6(\mathrm{~s}), 1355.1(\mathrm{~s}), 1272.3(\mathrm{~s}), 1214.7(\mathrm{~m})$, $1176.6(\mathrm{~m}), 1124.5(\mathrm{w}), 1099.3(\mathrm{w}), 1014.2(\mathrm{~m}), 880.9(\mathrm{~m}), 847.7$ (w), 736.2 (s), 696.5 (s), 599.6 (m); ${ }^{1} \mathrm{H}$ NMR (300 MHz, $\mathrm{CDCl}_{3}$ ) $\delta 7.39-7.00(\mathrm{~m}, 35 \mathrm{H}), 5.14-4.41(\mathrm{~m}, 16 \mathrm{H}), 4.37(\mathrm{t}, J=2.3,1 \mathrm{H})$, $4.26-4.17(\mathrm{~m}, 1 \mathrm{H}), 4.09(\mathrm{t}, J=9.5 \mathrm{~Hz}, 1 \mathrm{H}), 3.40(\mathrm{dd}, J=10.2$, $2.0 \mathrm{~Hz}, 1 \mathrm{H}), 2.91(\mathrm{~s}, 3 \mathrm{H}) ;{ }^{13} \mathrm{C} \mathrm{NMR}\left(75 \mathrm{MHz}, \mathrm{CDCl}_{3}\right) \delta 138.1$, 138.0, 136.6, 135.9 (d, $J=7.7 \mathrm{~Hz}), 135.7(\mathrm{~d}, J=6.8 \mathrm{~Hz}) 135.5$ $(\mathrm{d}, J=7.0 \mathrm{~Hz}), 128.6,128.4,128.34,128.3,128.2,128.1,128.0$, $128.0,127.9,127.9,127.8,127.3,79.9(\mathrm{~d}, J=4.5 \mathrm{~Hz}), 78.1(\mathrm{dd}$, $J=8.1,1.5 \mathrm{~Hz}), 77.7-77.6$ (m), 77.1, 75.3, 74.9, 74.8, 72.6, 69.9 $(\mathrm{d}, J=5.5 \mathrm{~Hz}), 69.6(\mathrm{~d}, J=5.6 \mathrm{~Hz}), 69.5(\mathrm{~d}, J=5.4 \mathrm{~Hz}), 39.3$; ${ }^{31} \mathrm{P}$ NMR $\left(121 \mathrm{MHz}, \mathrm{CDCl}_{3}\right) \delta-0.22,-0.53 ; \mathrm{m} / \mathrm{z}\left(\mathrm{ES}^{+}\right) 1071$ $\left([\mathrm{M}+\mathrm{Na}]^{+}, 100\right)$. Anal. Calcd for $\mathrm{C}_{56} \mathrm{H}_{58} \mathrm{O}_{14} \mathrm{P}_{2} \mathrm{~S}$ : C, 64.1; H, 5.6. Found: C, 64.0; H, 5.3.

(+)-1D-4-O-(Methylsulfonyl)-myo-inositol 1,5-Bisphosphate (Sodium Salt) (5). 23 (73 mg, $70 \mu \mathrm{mol})$ was dissolved in tertbutyl alcohol and water (10:1, $11 \mathrm{~mL})$, sodium hydrogen carbonate (24 mg, $280 \mu \mathrm{mol}$ ) and palladium black (149 mg, $1.4 \mathrm{mmol})$ were added, and the flask was flushed three times with a balloon of hydrogen and then stirred for $8 \mathrm{~h}$ at $\mathrm{rt}$ under an atmosphere of hydrogen. The organic layer was removed by filtration, the dark residue washed with water $(3 \times 5 \mathrm{~mL})$, and the collected aqueous layer lyophilized to yield $\mathbf{5}$ as a colorless solid (32 $\mathrm{mg}, 91 \%$ ): $[\alpha]_{\mathrm{D}}^{22}+1.64\left(c 0.3\right.$ in $\left.\mathrm{H}_{2} \mathrm{O}\right) ; v_{\max }(\mathrm{KBr}$ disk $) / \mathrm{cm}^{-1} 3448.9$ (s), $2969.2(\mathrm{~s}), 2924.4(\mathrm{~s}), 1655.1(\mathrm{~m}), 1340.9(\mathrm{~m}), 1158.0(\mathrm{~s}), 1107.8$ (s), $973.7(\mathrm{~s}), 942.6(\mathrm{w}), 869.9(\mathrm{w}), 802.8(\mathrm{w}), 724.5(\mathrm{w}), 598.6$ (w), $539.9(\mathrm{w}) ;{ }^{1} \mathrm{H}$ NMR $\left(300 \mathrm{MHz}, \mathrm{D}_{2} \mathrm{O}\right) \delta 4.60(\mathrm{t}, J=9.5 \mathrm{~Hz}$, $1 \mathrm{H}), 4.33(\mathrm{~m}, 1 \mathrm{H}), 4.00-3.91(\mathrm{~m}, 1 \mathrm{H}), 3.82-2.80(\mathrm{~m}, 2 \mathrm{H}), 3.75$ $(\mathrm{dd}, J=10.2,3.0 \mathrm{~Hz}, 1 \mathrm{H}), 3.25(\mathrm{~s}, 3 \mathrm{H}) ;{ }^{13} \mathrm{C} \mathrm{NMR}\left(75 \mathrm{MHz}, \mathrm{D}_{2} \mathrm{O}\right)$ $\delta 83.8(\mathrm{~d}, J=6.6 \mathrm{~Hz}), 75.0(\mathrm{~d}, J=5.5 \mathrm{~Hz}), 74.2(\mathrm{~d}, J=5.5 \mathrm{~Hz})$, $72.3(\mathrm{~d}, J=7.7 \mathrm{~Hz}), 70.8,68.3,38.9 ;{ }^{31} \mathrm{P}$ NMR $\left(121 \mathrm{MHz}, \mathrm{D}_{2} \mathrm{O}\right)$ $\delta$ 4.7, 4.1; HRMS $m / z,\left(\mathrm{ES}^{+}\right)$[found $\left[\mathrm{C}_{7} \mathrm{H}_{13} \mathrm{O}_{14} \mathrm{Na}_{4} \mathrm{P}_{2} \mathrm{~S}\right]^{+}$506.9090, $\mathrm{C}_{7} \mathrm{H}_{13} \mathrm{O}_{14} \mathrm{Na}_{4} \mathrm{P}_{2} \mathrm{~S}$ requires $\left.\mathrm{M}^{+}, 506.9092\right], \mathrm{m} / \mathrm{z}\left(\mathrm{ES}^{-}\right) ; 439\left(\left[\mathrm{C}_{7} \mathrm{H}_{14} \mathrm{O}_{14-}\right.\right.$ $\left.\left.\mathrm{NaP}_{2} \mathrm{~S}\right]^{-}, 5\right), 417\left(\left[\mathrm{C}_{7} \mathrm{H}_{15} \mathrm{O}_{14} \mathrm{P}_{2} \mathrm{~S}\right]^{-}, 15\right), 365$ (20), 343 (100), 321 (40), 303 (15), 208 (15).

(+)-1D-myo-Inositol 1,5-Bisphosphate (Sodium Salt) (24). 20 (100 mg, $103 \mu \mathrm{mol})(92 \mathrm{mg}, 94 \mu \mathrm{mol})$ was dissolved in tert-butyl alcohol and water $(5: 1,10 \mathrm{~mL})$, sodium hydrogen carbonate (32 $\mathrm{mg}, 377 \mu \mathrm{mol})$ and palladium black (201 mg, $1.9 \mathrm{mmol})$ were added, and the flask was flushed three times with a balloon of hydrogen and then stirred for $8 \mathrm{~h}$ at $\mathrm{rt}$ under an atmosphere of hydrogen. The organic layer was removed by filtration, the dark residue washed with water $(3 \times 5 \mathrm{~mL})$, and the collected aqueous layer lyophilized to yield $\mathbf{2 4}$ as a colorless solid (37 $\mathrm{mg}, 92 \%$ ): $[\alpha]_{\mathrm{D}}^{25}+5.7\left(c 0.53\right.$ in $\left.\mathrm{H}_{2} \mathrm{O}\right)\left[\right.$ lit. $^{41}\left[\alpha_{\mathrm{D}}^{25}+6.0\left(c 0.5\right.\right.$ in $\left.\left.\mathrm{H}_{2} \mathrm{O}\right)\right] ; v_{\max }$ $\left(\mathrm{KBr}\right.$ disk) $/ \mathrm{cm}^{-1} 3423.5$ (s), $2930.0(\mathrm{~m}), 1655.1(\mathrm{~m}), 1560.7(\mathrm{w})$, $1376.3(\mathrm{w}), 1094.1(\mathrm{~s}), 968.2(\mathrm{~s}), 897.9(\mathrm{w}), 808.6(\mathrm{~m}), 718.9(\mathrm{~m})$, $568.0(\mathrm{~m}) ;{ }^{1} \mathrm{H}$ NMR $\left(300 \mathrm{MHz}, \mathrm{D}_{2} \mathrm{O}\right) \delta 4.18(\mathrm{t}, J=2.8 \mathrm{~Hz}, 1 \mathrm{H})$, $3.87-3.81(\mathrm{~m}, 1 \mathrm{H}), 3.75-3.64(\mathrm{~m}, 3 \mathrm{H}), 3.53(\mathrm{dd}, J=9.5,2.8 \mathrm{~Hz}$, $1 \mathrm{H}) ;{ }^{13} \mathrm{C}$ NMR $\left(75 \mathrm{MHz}, \mathrm{D}_{2} \mathrm{O}\right) \delta 78.3(\mathrm{~d}, J=5.6 \mathrm{~Hz}), 74.6$ $(\mathrm{d}, J=5.1 \mathrm{~Hz}), 72.6(\mathrm{~d}, J=1.5 \mathrm{~Hz}), 71.9(\mathrm{t}, J=5.0 \mathrm{~Hz}), 71.6$, 71.0; ${ }^{31} \mathrm{P}$ NMR $\left(121 \mathrm{MHz}, \mathrm{D}_{2} \mathrm{O}\right) \delta 5.4,4.5 ; \mathrm{m} / \mathrm{z}\left(\mathrm{ES}^{-}\right) 405$ $\left(\left[\mathrm{C}_{6} \mathrm{H}_{10} \mathrm{Na}_{3} \mathrm{O}_{12} \mathrm{P}_{2}\right]^{-}, 15\right), 383\left(\left[\mathrm{C}_{6} \mathrm{H}_{11} \mathrm{Na}_{2} \mathrm{O}_{12} \mathrm{P}_{2}\right]^{-}, 20\right), 361\left(\left[\mathrm{C}_{6} \mathrm{H}_{12}-\right.\right.$ $\left.\left.\mathrm{NaO}_{12} \mathrm{P}_{2}\right]^{-}, 50\right), 339\left(\left[\mathrm{C}_{6} \mathrm{H}_{13} \mathrm{O}_{12} \mathrm{P}_{2}\right]^{-}, 45\right), 281\left(\left[\mathrm{C}_{6} \mathrm{H}_{11} \mathrm{NaO}_{9} \mathrm{P}\right]^{-}, 70\right)$, $259\left(\left[\mathrm{C}_{6} \mathrm{H}_{12} \mathrm{O}_{9} \mathrm{P}\right]^{-}, 100\right)$. These data are in good agreement with the literature values. ${ }^{41}$

$(-)-1 \mathrm{D}-1,5-\mathrm{Bis}-O$-allyl-4- $O$-[2-(allyloxy)ethyl]-2,3,6-tris- $O$-benzyl-myo-inositol (25). $11(170 \mathrm{mg}, 320 \mu \mathrm{mol})$ was dissolved in dry $\mathrm{N}, \mathrm{N}$-dimethylformamide $(5 \mathrm{~mL})$ under an atmosphere of nitrogen. The resulting solution was cooled to $0{ }^{\circ} \mathrm{C}$ and sodium hydride (60\% (w/w), $15 \mathrm{mg}, 384 \mu \mathrm{mol})$ added with stirring. The mixture was allowed to warm to rt and stirred for $2 \mathrm{~h}$, it was then recooled to $0{ }^{\circ} \mathrm{C}$, and tetra- $n$-butylammonium iodide (catalytic amount) and 2-(allyloxy)ethyl bromide ( $48 \mu \mathrm{L}, 63 \mathrm{mg}, 384 \mu \mathrm{mol}$ ) were added. The resulting mixture was allowed to warm to rt and stirred overnight. The sodium hydride was quenched with water $(0.5 \mathrm{~mL})$, the solvent removed under reduced pressure, and the residue reconstituted with ethyl acetate $(10 \mathrm{~mL})$ and water $(10 \mathrm{~mL})$. The layers were separated, and the aqueous layer was extracted with ethyl acetate $(3 \times 5 \mathrm{~mL})$. The combined organic layers were washed with brine $(10 \mathrm{~mL})$, dried (magnesium sulfate), filtered, and concentrated under reduced pressure. Purification by silica gel column chromatography, eluting with ethyl acetate and petroleum ether (10:90), gave 25 (158 $\mathrm{mg}, 80 \%$ ) as a colorless oil: $R_{f} 0.6$ (ethyl acetate/petroleum ether, 30:70); $[\alpha]_{\mathrm{D}}^{25}-7.8$ (c 0.51 in $\left.\mathrm{CHCl}_{3}\right) ; v_{\max }$ (thin film) $/ \mathrm{cm}^{-1} 3064.0(\mathrm{~m}), 3031.6(\mathrm{~m}), 2984.1(\mathrm{~s})$, 2869.3 (s), 1647.2 (w), $1496.9(\mathrm{w}), 1454.9$ (m), 1421.2 (w), 1266.0 $(\mathrm{s}), 1208.6(\mathrm{w}), 1131.9(\mathrm{~m}), 1086.6(\mathrm{~s}), 1028.1(\mathrm{~m}), 996.0(\mathrm{w})$, $926.4(\mathrm{~m}), 737.3$ (s), $699.3(\mathrm{~m}) ;{ }^{1} \mathrm{H}$ NMR $\left(300 \mathrm{MHz}, \mathrm{CDCl}_{3}\right) \delta$ $7.43-7.29(\mathrm{~m}, 15 \mathrm{H}), 6.06-5.83(\mathrm{~m}, 3 \mathrm{H}), 5.32-5.12(\mathrm{~m}, 6 \mathrm{H}), 4.86$ $(\mathrm{s}, 2 \mathrm{H}), 4.85(\mathrm{~d}, J=10.2 \mathrm{~Hz}, 1 \mathrm{H}), 4.78(\mathrm{~d}, J=10.2 \mathrm{~Hz}, 1 \mathrm{H}), 4.72$ $(\mathrm{d}, J=11.8 \mathrm{~Hz}, 1 \mathrm{H}), 4.59(\mathrm{~d}, J=11.8 \mathrm{~Hz}, 1 \mathrm{H}), 4.43-4.28(\mathrm{~m}$, $2 \mathrm{H}), 4.10-4.06(\mathrm{~m}, 2 \mathrm{H}), 4.02-3.89(\mathrm{~m}, 6 \mathrm{H}), 3.82(\mathrm{t}, J=9.5 \mathrm{~Hz}$, $1 \mathrm{H}), 3.61(\mathrm{t}, J=4.9 \mathrm{~Hz}, 2 \mathrm{H}), 3.29(\mathrm{~d}, J=9.2 \mathrm{~Hz}, 1 \mathrm{H}), 3.27$ (dd, $J=9.7,5.9 \mathrm{~Hz}, 1 \mathrm{H}), 3.18(\mathrm{dd}, J=9.7,2.3 \mathrm{~Hz}, 1 \mathrm{H}) ;{ }^{13} \mathrm{C} \mathrm{NMR}$ $\left(75 \mathrm{MHz}, \mathrm{CDCl}_{3}\right) \delta 139.05,139.0,138.7,135.6,135.0,134.9$, $128.3,128.3,128.1,127.8,127.6,127.5,127.3,116.8,116.6,116.4$, 83.1, 82.5, 81.6, 80.53, 80.5, 75.9, 74.6, 74.5, 74.0, 72.9, 72.7, 72.0, 71.7, 69.9; HRMS $\mathrm{m} / \mathrm{z}\left(\mathrm{ES}^{+}\right)$[found $(\mathrm{M}+\mathrm{Na})^{+}$637.3140, $\mathrm{C}_{38} \mathrm{H}_{46} \mathrm{O}_{7} \mathrm{Na}$ requires $\left.\mathrm{M}^{+}, 637.3141\right], \mathrm{m} / z\left(\mathrm{ES}^{+}\right) 637\left([\mathrm{M}+\mathrm{Na}]^{+}\right.$, 100).

(-)-1D-4-O-(2-Hydroxyethyl)-2,3,6-tris- $O$-benzyl-myo-inositol (26). Wilkinson's catalyst ( $53 \mathrm{mg}, 49 \mu \mathrm{mol}$ ) was dissolved in dry tetrahydrofuran $(1.0 \mathrm{~mL})$ under an atmosphere of nitrogen, $n$-butyllithium (1.6 M solution in hexanes, $308 \mu \mathrm{L}, 207 \mu \mathrm{mol}$ ) was added, and the resulting mixture was stirred for $10 \mathrm{~min}$ at $\mathrm{rt}$. The mixture was then cannulated onto a solution of $\mathbf{2 5}$ (303 $\mathrm{mg}, 493$ $u \mathrm{~mol})$ in dry tetrahydrofuran $(0.5 \mathrm{~mL})$ under an atmosphere of nitrogen and the resulting mixture heated under reflux for $6 \mathrm{~h}$. The mixture was cooled to $\mathrm{rt}$ and the solvent removed under reduced pressure to give a dark red residue. ${ }^{1} \mathrm{H}$ NMR analysis indicated that the allyl groups had completely isomerized. The residue was dissolved in a mixture of methanol and dichloromethane $(2: 3,5$

(41) Westerduin, P.; Willems, H. A. M.; Vanboeckel, C. A. A Tetrahedron Lett. 1990, 31, 6915. 
$\mathrm{mL}$ ) under an atmosphere of nitrogen, acetyl chloride (23 mg, 21 $\mu \mathrm{L}, 296 \mu \mathrm{mol})$ was added, and the resulting solution was stirred for $2 \mathrm{~h}$. The generated hydrochloric acid was quenched with triethylamine $(0.2 \mathrm{~mL})$, the solvent removed under reduced pressure, and the residue adsorbed onto silica gel and purified using silica gel column chromatography, eluting with ethyl acetate and petroleum ether (60:40), to give $\mathbf{2 6}$ (195 $\mathrm{mg}, \mathbf{8 0 \%}$ ) as a colorless solid. A very pure sample was obtained by crystallization from ethyl acetate and petroleum ether: $R_{f} 0.46$ (ethyl acetate/petroleum ether, 60:40); $[\alpha]_{\mathrm{D}}^{25}-0.45$ (c 1.1 in $\mathrm{CHCl}_{3}$ ); mp 92-93 ${ }^{\circ} \mathrm{C}$ (from ethyl acetate/petroleum ether); $v_{\max }\left(\mathrm{KBr}\right.$ disk $/ \mathrm{cm}^{-1} 3398.6$ (s), 3064.4 (w), $3025.2(\mathrm{w}), 2911.9(\mathrm{~m}), 2873.9(\mathrm{~m}), 1496.9(\mathrm{w}), 1454.7(\mathrm{~m})$, $1364.5(\mathrm{~m}), 1249.1(\mathrm{w}), 1208.9(\mathrm{w}), 1131.7$ (s), $1085.6(\mathrm{~s}), 2068.5$ (s), $1023.2(\mathrm{~s}), 928.7(\mathrm{w}), 723.3(\mathrm{~s}), 969.8(\mathrm{~s}), 607.0(\mathrm{w}), 539.9$ (w); ${ }^{1} \mathrm{H}$ NMR $\left(300 \mathrm{MHz}, \mathrm{CDCl}_{3}\right) \delta 7.37-7.29(\mathrm{~m}, 15 \mathrm{H}), 5.00(\mathrm{~d}$, $J=11.8 \mathrm{~Hz}, 1 \mathrm{H}), 4.89\left(1 \mathrm{H}, \mathrm{d}, J_{\mathrm{A}^{\prime} \mathrm{B}^{\prime}}=11.3 \mathrm{~Hz}, \mathrm{OCH}_{\mathrm{A}^{\prime}} \mathrm{H}_{\mathrm{B}^{\prime}}\right), 4.80$ $\left(1 \mathrm{H}, \mathrm{d}, J_{\mathrm{A}^{\prime} \mathrm{B}^{\prime}}=11.3 \mathrm{~Hz}, \mathrm{OCH}_{\mathrm{A}^{\prime}} H_{\mathrm{B}^{\prime}}\right), 4.70\left(1 \mathrm{H}, \mathrm{d}, J_{\mathrm{A}^{\prime} \mathrm{B}^{\prime}}=11.8 \mathrm{~Hz}\right.$, $\left.\mathrm{OCH}_{\mathrm{A}} H_{\mathrm{B}}\right), 4.69\left(2 \mathrm{H}, \mathrm{s}, \mathrm{OCH}_{\mathrm{A}^{\prime \prime}} H_{\mathrm{B}^{\prime \prime}}\right), 4.05-3.46(\mathrm{~m}, 9 \mathrm{H}), 3.37(1 \mathrm{H}$, dd, $J 9.7,2.3$, inositol ring), $3.30(1 \mathrm{H}$, br s, $\mathrm{OH}), 3.06(1 \mathrm{H}$, br s, $\mathrm{OH}), 2.26(1 \mathrm{H}, \mathrm{d}, J 7,4, \mathrm{OH}) ;{ }^{13} \mathrm{C} \mathrm{NMR}\left(75 \mathrm{MHz}, \mathrm{CDCl}_{3}\right) \delta 138.5$, $138.49,137.8,128.6,128.55,128.5,128.1,127.95,127.93,127.9$, 127.8, 127.7, 82.1, 81.5, 80.6, 77.2, 75.0, 74.91, 74.9, 74.7, 72.8, 72.3, 62.2; HRMS $\mathrm{m} / \mathrm{z}\left(\mathrm{ES}^{+}\right)$[found $(\mathrm{M}+\mathrm{Na})^{+}$517.2192, $\mathrm{C}_{29} \mathrm{H}_{34} \mathrm{O}_{7} \mathrm{Na}$ requires $\left.\mathrm{M}^{+}, 517.2202\right], m / z\left(\mathrm{ES}^{+}\right) 517\left([\mathrm{M}+\mathrm{Na}]^{+}\right.$, 100). Anal. Calcd for $\mathrm{C}_{29} \mathrm{H}_{34} \mathrm{O}_{7}$ : C, 70.4; H, 6.9. Found: C, 70.4; H, 6.8.

(+)-1D-4-O-[2-[(Dibenzylphosphoryl)oxy]ethyl]-2,3,6-tris- $O$ benzyl-myo-inositol 1,5-Bis(dibenzyl phosphate) (27). Bis(benzyloxy)( $N, N$-diisopropylamino)phosphine $(1.00 \mathrm{~g}, 2.9 \mathrm{mmol})$ was stirred with $1 H$-tetrazole $(0.43 \mathrm{M}$ solution in acetonitrile, $6.9 \mathrm{~mL}$, $2.9 \mathrm{mmol}$ ) for $30 \mathrm{~min}$ under an atmosphere of nitrogen. 26 (195 $\mathrm{mg}, 394 \mu \mathrm{mol})$ dissolved in dry dichloromethane $(8 \mathrm{~mL})$ was added by cannula and the resulting mixture stirred overnight. The mixture was cooled to $-78{ }^{\circ} \mathrm{C}$, and 3-chloroperoxybenzoic acid $(510 \mathrm{mg}$, $2.9 \mathrm{mmol}$ ) was added. The resulting mixture was allowed to warm to $\mathrm{rt}$ and stirred for $30 \mathrm{~min}$. The 3-chloroperoxybenzoic acid was quenched with a $10 \%$ aqueous solution of sodium hydrogen sulfite $(10 \mathrm{~mL})$. The layers were separated, and the aqueous layer was extracted with dichloromethane $(3 \times 10 \mathrm{~mL})$. The combined organic layers were washed with a saturated aqueous solution of sodium hydrogen carbonate $(10 \mathrm{~mL})$, dried (magnesium sulfate), filtered, and concentrated under reduced pressure. Purification by silica gel column chromatography, eluting with ethyl acetate and petroleum ether (40:60, then 60:40), gave $27(232 \mathrm{mg}, 46 \%)$ as a colorless oil: $R_{f} 0.54$ (ethyl acetate/petroleum ether, 80:20); $[\alpha]_{\mathrm{D}}^{25}+9.7(c$ 0.88 in $\mathrm{CHCl}_{3}$ ); $v_{\max }$ (thin film) $/ \mathrm{cm}^{-1} 3064.3$ (w), 3033.2 (w), $2948.6(\mathrm{~m}), 2885.2(\mathrm{~m}), 1497.5(\mathrm{~m}), 1455.6(\mathrm{~s}), 1273.7(\mathrm{~s}), 1214.7$ (m), 1012.1 (s), 920.3 (w), 881.7 (m), 736.5 (s), 696.4 (s); ${ }^{1} \mathrm{H}$ NMR $\left(300 \mathrm{MHz}, \mathrm{CDCl}_{3}\right) \delta 7.28-6.97(\mathrm{~m}, 45 \mathrm{H}), 4.98-4.50(\mathrm{~s}, 14 \mathrm{H})$, $4.89-4.59(\mathrm{~m}, 19 \mathrm{H}), 4.46(\mathrm{~d}, J=11.8 \mathrm{~Hz}, 1 \mathrm{H}), 4.37(\mathrm{~d}, J=11.8$ $\mathrm{Hz}, 1 \mathrm{H}), 4.15(\mathrm{t}, J=2.0 \mathrm{~Hz}, 1 \mathrm{H}), 4.09-3.84(\mathrm{~m}, 5 \mathrm{H}), 3.74(\mathrm{t}, J$ $=9.5 \mathrm{~Hz}, 2 \mathrm{H}), 3.09(\mathrm{dd}, J=9.7,2.0 \mathrm{~Hz}, 1 \mathrm{H}) ;{ }^{13} \mathrm{C} \mathrm{NMR}(75 \mathrm{MHz}$, $\left.\mathrm{CDCl}_{3}\right) \delta 138.5,138.1,137.7,136.0-135.5(\mathrm{~m}), 128.52,128.5$, $128.4,128.3,128.24,128.2,128.1,127.84,127.8,127.7,127.6$, 127.5, 127.4, 127.3, $80.4(\mathrm{~d}, J=6.6 \mathrm{~Hz}), 79.9(\mathrm{~d}, J=1.7 \mathrm{~Hz})$, 79.3, $78.1(\mathrm{dd}, J=11.4,4.0 \mathrm{~Hz}), 77.9(\mathrm{~d}, J=5.9 \mathrm{~Hz}), 76.0,75.1$, 74.6, 72.7, $71.6(\mathrm{~d}, J=7.8 \mathrm{~Hz}), 69.4(\mathrm{~d}, J=5.9 \mathrm{~Hz}), 69.3-69.2$ (m) $69.0(\mathrm{~d}, J=5.7 \mathrm{~Hz}), 66.9(\mathrm{~d}, J=6.1 \mathrm{~Hz}) ;{ }^{31} \mathrm{P}$ NMR $(121$ $\left.\mathrm{MHz}, \mathrm{CDCl}_{3}\right) \delta 0.38,-0.35,-0.61 ; \mathrm{m} / z\left(\mathrm{ES}^{+}\right) 1297\left([\mathrm{M}+\mathrm{Na}]^{+}\right.$, 100). Anal. Calcd for $\mathrm{C}_{71} \mathrm{H}_{73} \mathrm{O}_{16} \mathrm{P}_{3}$ : C, 66.9; H, 5.8. Found: $\mathrm{C}$, $66.7 ; \mathrm{H}, 5.8$.

(-)-1D-4-O-[2-(Phosphoryloxy)ethyl]-myo-inositol 1,5-Bisphosphate (Sodium Salt) (6). 27 (97 mg, $76 \mu \mathrm{mol}, 1.0)$ was dissolved in tert-butyl alcohol and water $(5: 1,12 \mathrm{~mL})$, sodium hydrogen carbonate $(38 \mathrm{mg}, 455 \mu \mathrm{mol})$ and palladium black (162 mg, 1.5 mmol) were added, and the flask was flushed three times with a balloon of hydrogen and then stirred for $8 \mathrm{~h}$ at $\mathrm{rt}$ under an atmosphere of hydrogen. The organic layer was removed by filtration, the dark residue washed with water $(3 \times 5 \mathrm{~mL})$, and the collected aqueous layer lyophilized to yield $\mathbf{6}$ as a colorless solid (40 mg, 89\%): $[\alpha]_{\mathrm{D}}^{25}-2.95\left(c 0.44\right.$ in $\mathrm{H}_{2} \mathrm{O}$ ); $v_{\max }(\mathrm{KBr}$ disk)/ $\mathrm{cm}^{-1} 3290.0(\mathrm{~s}), 2963.6(\mathrm{~m}), 2930.0(\mathrm{~m}), 1655.1(\mathrm{~s}), 1639.2(\mathrm{~s})$, 1093.2 (s), 978.3 (s), 802.8 (w), 721.7 (w), 550.5 (m); ${ }^{1} \mathrm{H}$ NMR (300 MHz, $\left.\mathrm{D}_{2} \mathrm{O}\right) \delta 4.30$ (br s, $\left.1 \mathrm{H}\right), 4.11-4.06(\mathrm{~m}, 1 \mathrm{H}), 3.81-3.69$ $(\mathrm{m}, 6 \mathrm{H}), 3.58-3.45(\mathrm{~m}, 2 \mathrm{H}) ;{ }^{13} \mathrm{C}$ NMR $\left(75 \mathrm{MHz}, \mathrm{D}_{2} \mathrm{O}\right) \delta 81.3(\mathrm{~d}$, $J=6.0 \mathrm{~Hz}), 78.4(\mathrm{~d}, J=5.4 \mathrm{~Hz}), 74.8(\mathrm{~d}, J=5.7 \mathrm{~Hz}), 73.2(\mathrm{~d}$, $J=7.3 \mathrm{~Hz}), 72.8(\mathrm{~d}, J=7.0 \mathrm{~Hz}), 70.9,69.9,64.2(\mathrm{~d}, J=4.5 \mathrm{~Hz})$; ${ }^{31} \mathrm{P}$ NMR $\left(121 \mathrm{MHz}, \mathrm{D}_{2} \mathrm{O}\right) \delta 5.2,4.9,4.1 ; \mathrm{HRMS} / z\left(\mathrm{ES}^{+}\right)$[found $(\mathrm{M}+\mathrm{H})^{+}$596.8883, $\mathrm{C}_{8} \mathrm{H}_{14} \mathrm{O}_{16} \mathrm{Na}_{6} \mathrm{P}_{3}$ requires $\left.\mathrm{M}^{+}, 596.8881\right], \mathrm{m} / \mathrm{z}$ $\left(\mathrm{ES}^{+}\right), 597\left([\mathrm{M}+\mathrm{H}]^{+}, 50\right), 289$ (100).

${ }^{45} \mathrm{Ca}^{2+}$ Flux Assay. L15 cells were obtained by stable exogenous expression of Ins $P_{3} \mathrm{R} 1$ in L fibroblasts. ${ }^{42,43}$ The cells were cultured in Dulbecco's modified Eagle's medium supplemented with $10 \%$ fetal calf serum, $3.8 \mathrm{mM}$ L-glutamine, $0.9 \%$ (v/v) nonessential amino acids, $85 \mathrm{IU} / \mathrm{mL}$ penicillin, $85 \mu \mathrm{g} / \mathrm{mL}$ streptomycin, and 20 $\mathrm{mM}$ HEPES, $\mathrm{pH}$ 7.4.

${ }^{45} \mathrm{Ca}^{2+}$ fluxes were performed on saponin-permeabilized cells. The cells were seeded in 12-well clusters (Costar, Cambridge, MA) at a density of approximately $4 \times 10^{4} \mathrm{~cm}^{-2}$. Experiments were carried out on confluent monolayers of cells at the seventh day after plating. The cells were permeabilized by incubating them for $10 \mathrm{~min}$ with a solution containing $120 \mathrm{mM} \mathrm{KCl}, 30 \mathrm{mM}$ imidazole hydrochloride, $\mathrm{pH}$ 6.8, $2 \mathrm{mM} \mathrm{MgCl} 2,1 \mathrm{mM}$ ATP, $1 \mathrm{mM}$ EGTA, and $20 \mu \mathrm{g} / \mathrm{mL}$ saponin at $25^{\circ} \mathrm{C}$. The nonmitochondrial $\mathrm{Ca}^{2+}$ stores were loaded for $45 \mathrm{~min}$ at $25^{\circ} \mathrm{C}$ in $120 \mathrm{mM} \mathrm{KCl}, 30 \mathrm{mM}$ imidazole

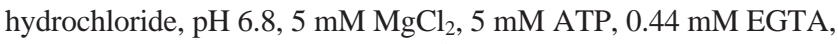
$10 \mathrm{mM} \mathrm{NaN}$, and $150 \mathrm{nM}$ free ${ }^{45} \mathrm{Ca}^{2+}(28 \mu \mathrm{Ci} / \mathrm{mL})$. The cells were then washed twice with $1 \mathrm{~mL}$ of efflux medium containing $120 \mathrm{mM} \mathrm{KCl}, 30 \mathrm{mM}$ imidazole hydrochloride, $\mathrm{pH}$ 6.8, $1 \mathrm{mM}$ EGTA, and $10 \mu \mathrm{M}$ thapsigargin (TG). The efflux medium was replaced every $2 \mathrm{~min}$, and the efflux was performed at $25^{\circ} \mathrm{C}$. The additions of $\operatorname{Ins} P_{3}$ and the 4-position-modified compounds are indicated in the figures. At the end of the experiment, the ${ }^{45} \mathrm{Ca}^{2+}$ remaining in the stores was released by incubation with $1 \mathrm{~mL}$ of a $2 \%$ sodium dodecyl sulfate solution for $30 \mathrm{~min}$. $\mathrm{Ca}^{2+}$ release is plotted as the fractional loss (i.e., the amount of $\mathrm{Ca}^{2+}$ released in 2 min divided by the total store $\mathrm{Ca}^{2+}$ content at that time). The latter value was calculated by summing in retrograde order the amount of tracer remaining in the cells at the end of the efflux and the amounts of tracer collected during the successive time intervals.

Acknowledgment. This work was funded by the Biotechnology and Biological Sciences Research Council (BBSRC; U.K.) (Grant Number BB/C515255/1) and the University of St Andrews. We are grateful to the technical staff of the University of St Andrews for providing mass spectrometry and elemental analysis data. We are grateful to Tomas Luyten for technical assistance. H.L.R. thanks the Royal Society for a Research Fellowship.

Supporting Information Available: General experimental methods, ${ }^{1} \mathrm{H},{ }^{13} \mathrm{C}$, and, where appropriate, ${ }^{31} \mathrm{P}$ NMR spectra for all reported compounds, raw data from the ${ }^{45} \mathrm{Ca}^{2+}$ flux assay, and CIF file for the X-ray crystal structure of compound 20. This material is available free of charge via the Internet at http://pubs.ac.org.

JO070611A

(42) Mackrill, J. J.; Wilcox, R. A.; Miyawaki, A.; Mikoshiba, K.; Nahorski, S. R.; Challiss, R. A. J. Biochem. J. 1996, 318, 871.

(43) Miyawaki, A.; Furuichi, T.; Maeda, N.; Mikoshiba, K. Neuron 1990 5,11 . 